University of Tennessee Law

Legal Scholarship Repository: A Service of the Joel A. Katz Library

UTK Law Faculty Publications

2019

Biological Citizenship and the Children of Same-Sex Marriage

Michael J. Higdon

Follow this and additional works at: https://ir.law.utk.edu/utklaw_facpubs

Part of the Law Commons 


\section{University of Tennessee College of Law}

From the SelectedWorks of Michael J Higdon

2019

\section{Biological Citizenship and the Children of Same- Sex Marriage}

Michael J Higdon 


\title{
Biological Citizenship and the Children of Same-Sex Marriage
}

\begin{abstract}
Michael J. Higdon*
Abstract

In 2015, the Supreme Court ruled that states could not, consistent with the Due Process Clause, deny same-sex couples the right to marry. To allow otherwise, said the Court, would "harm and humiliate the children of same-sex couples." Thus, it was hoped that marriage equality would provide greater security for the children of same-sex couples. And the need for such protections are increasingly important given that, with advances in assisted-reproduction techniques, it is easier than ever for same-sex couples to become parents. Indeed, when it comes to procreation, same-sex marriages and opposite-sex marriages are becoming much more alike. But there remains an obvious difference between the two. Namely, same-sex couples are unable to procreate without the assistance of a third-party, meaning that although both parents in a same-sex marriage may qualify as legal parents, only one (at most) will qualify as a biological parent. But from a constitutional perspective, should that distinction matter?

The Supreme Court, in both Obergefell and its recent decision in Pavan $\mathrm{v}$. Smith has indicated that when it comes to the governmental benefits associated with marriage, the answer is "no." Nonetheless, within the realm of immigration law, the State Department uses the absence of biological ties against the children of same-sex marriage and, on that basis, denies them United States citizenship. Although nothing in the Immigration and Naturalization Act requires that citizens, in order to transmit citizenship, possess a biological relationship with their children born abroad, the State Department has begun denying citizenship petitions on behalf of children from same-sex couples simply because the citizen parent, despite being the child's legal parent, is not the biological parent. This Article argues that the State Department's approach is not only unreasonable and, thus, not entitled to Chevron deference, but more importantly, is an unconstitutional infringement of both the right to marry and the right to parent, as those rights have developed by the Supreme Court. In sum, the State Department's practice provides a poignant example of both the ongoing discrimination and the challenging questions that remain, postObergefell, in the quest for true marriage equality.
\end{abstract}

\section{TABle of Contents}

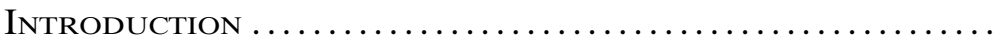

I. Parenthood and the Conferral of Citizenship UNDER THE INA

* Professor of Law, University of Tennessee College of Law.

January 2019 Vol. 87 No. 1 
II. Same Sex Marriage, Parental Rights, and the

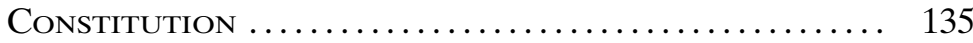

A. The Fundamental Right to Marry .............. 137

B. The Fundamental Rights of Parents ............. 143

1. Parental Custody and Control ............. 144

2. Parental Identity ....................... 147

III. The State Department's Interpretation: UNREASONABLE AND UNCONSTITUTIONAL .......... 153

A. Chevron Deference ...................... 153

B. The Fundamental Rights of Same-Sex Parents...... 155

1. The Right to Marry .................... 156

2. Right to Parent ...................... 161

a. Constitutional Parenthood Is Broader Than Biological Parenthood ................. 163

b. Constitutional Parenthood Protects Existing Families........................... 164

c. Constitutional Parenthood Cannot Infringe upon Reproductive Freedom ............ 166

Conclusion ................................................ 169

\section{INTRODUCTION}

[T]he circumstances that enabled the law's tidy assumptions linking parenthood with biology and adoption have collapsed. ${ }^{1}$

Aiden Dvash-Banks has a twin brother named Ethan. The two boys were born in Canada just four minutes apart. Aiden was born a United States citizen; his brother was not. How can that be?

Although this may sound like a riddle, it is instead an increasing reality for children born abroad to same-sex couples. Aiden and Ethan were born to two men: Andrew, who is a United States citizen, and Elad, who is a citizen of Israel. ${ }^{2}$ In 2010, the couple married in Canada. ${ }^{3}$ Desiring a family, the couple used an anonymous egg donor and a gestational surrogate, and in 2016, Aiden and Ethan were born. The two boys have the same biological mother (i.e., the anonymous

1 David D. Meyer, The Constitutionality of “Best Interests" Parentage, 14 WM. \& MARY BiLl RTs. J. 857, 860 (2006).

2 The details of the Dvash-Banks attempts to have the government recognize the citizenship status of their children are all taken from the complaint filed on their behalf by Immigration Equality. See Complaint, Dvash-Banks v. Dep't of State, No. 2:18-cv-00523 (C.D. Cal. Jan. 28, 2018).

3 Id. at 11. 
egg donor) but different biological fathers. ${ }^{4}$ Andrew is Aiden's biological father, while Elad is the biological father of Ethan. ${ }^{5}$ Under Canadian law, both Andrew and Elad are the twins' legal parents and are listed as such on the twins' birth certificates. ${ }^{6}$

Subsequently, the family decided to emigrate to the United States. As a U.S. citizen, Andrew could do so as a matter of right. ${ }^{7}$ Likewise, Elad, as the spouse of a U.S. citizen, could enter the United States under a family-based visa. ${ }^{8}$ But what of their children? In most instances, a child born abroad to a U.S. citizen inherits that citizenship so long as the parent lived in the United States for the requisite amount of time, ${ }^{9}$ which Andrew did. Thus, it would seem that the twins would qualify as American citizens. The government disagreed. The State Department did recognize Aiden's claim, given that he is both the legal and the biological child of Andrew. When it came to Ethan, however, the State Department denied his claim for citizenship because although he was Andrew's legal child, he was not Andrew's biological child. ${ }^{10}$ In fact, Ethan was only permitted to enter the country after the family successfully obtained a tourist visa for him. ${ }^{11}$ As a result, Ethan is the only member of his family who currently may not live in the United States permanently. ${ }^{12}$

In essence, the State Department refused to recognize Andrew as the parent of Ethan. It did so by treating the twins as being born "out of wedlock," a condition that triggers a separate statutory provision of the Immigration and Naturalization Act ("INA"), one that requires a

4 Id. at 2.

5 Id.

$6 I d$. For a discussion on the evolution of Canadian law as it relates to same-sex parents and birth certificates, see Paula Gerber \& Phoebe Irving Lindner, Birth Certificates for Children with Same-Sex Parents: A Reflection of Biology or Something More?, 18 N.Y.U. J. Legis. \& Pub. Pol'y 225, 270-73 (2015).

7 See Complaint, supra note 2, at 4.

8 Id.

9 See infra Part I.

10 Complaint, supra note 2, at 3.

11 Id. at 15.

12 Although the couple is attempting to secure legal permanent resident status for Ethan, such status "falls short of birthright citizenship and typically would be sought only if his father was an immigrant who had become a U.S. citizen, rather than an American citizen from birth." Maria Sacchetti, In Lawsuits, Same-Sex Couples Say U.S. Wrongly Denied Their Children Citizenship, WASH. Post (Jan. 22, 2018), https://www.washingtonpost.com/local/immigration/in-law suits-same-sex-couples-say-us-wrongly-denied-their-children-citizenship/2018/01/22/1c83c98a-fd3 4-11e7-8f66-2df0b94bb98a_story.html?utm_term=.c42c1b392545 [https://perma.cc/FFY6BUUD]. 
"blood relationship." 13 The problem is that the twins were not born out of wedlock - they were born to two men who were legally married to one another. Nonetheless, because the two men were "merely" the legal parents and not the two biological parents, the State Department relied on a provision found in an appendix of the Foreign Affairs Manual-a provision never submitted for notice and comment-to treat the twins as nonmarital. ${ }^{14}$ As such, in the eyes of the State Department, a biological connection to the U.S. citizen parent was required, and only Aiden could establish that relationship.

This Article suggests that the State Department's approach is not only bad policy-it is also unconstitutional. Of course, when it comes to immigration law, the federal government has plenary power. As the Court has famously stated, "in the exercise of its broad power over immigration and naturalization, 'Congress regularly makes rules that would be unacceptable if applied to citizens.'" 15 But that is precisely the problem with the government's position-this discrimination is impacting the constitutional rights of citizens. After all, as the Supreme Court has noted, citizens, even when living abroad, are entitled to full constitutional protection. ${ }^{16}$

Although other scholars have discussed the harms that arise from requiring biological parentage as a condition precedent to the conferral of citizenship, ${ }^{17}$ with the Court's decision in Obergefell v. Hodges, ${ }^{18}$ a new dimension to that problem has emerged. Specifically, such a requirement infringes upon same-sex couples' fundamental right to marry as that right was interpreted in Obergefell (and subsequently reinforced in Pavan v. Smith ${ }^{19}$ ), given that it withholds from those couples an important aspect of the "constellation of benefits" linked

138 U.S.C. $\S 1409$ (a)(1) (2012).

14 See Complaint, supra note 2, at 10; 7 U.S. Dep't of State, Foreign Affairs Manual $\S 1140$, app. E (2014).

15 Fiallo v. Bell, 430 U.S. 787, 792 (1977) (quoting Mathews v. Diaz, 426 U.S. 67, 80 (1976)).

16 See, e.g., Reid v. Covert, 354 U.S. 1, 5-6 (1957) ("At the beginning we reject the idea that when the United States acts against citizens abroad it can do so free of the Bill of Rights.").

17 See, e.g., Kristine S. Knaplund, Baby Without A Country: Determining Citizenship for Assisted Reproduction Children Born Overseas, 91 Denv. U. L. Rev. 335, 335 (2014) (proposing "a workable solution to the question of citizenship for children born overseas to American parents via [assisted reproductive technology]"); Scott Titshaw, Sorry Ma'am, Your Baby Is an Alien: Outdated Immigration Rules and Assisted Reproductive Technology, 12 Fla. COASTAL L. REv. 47, 55 (2010) (arguing that "children conceived through [assisted reproductive technology] should be recognized for purposes of U.S. citizenship transmission at birth if they were not born out of wedlock").

18135 S. Ct. 2584 (2015).

19137 S. Ct. 2075 (2017). 
to marriage..$^{20}$ Namely, it denies them the right to transmit their citizenship to children born into their marriages-a right explicitly provided by the INA. ${ }^{21}$ Relatedly, the State Department's interpretation also infringes upon same-sex parents' fundamental right to parent their children as that right has developed in a long line of cases going back almost a hundred years. ${ }^{22}$ The State Department treats them as legal strangers to their legal children, a conclusion that cannot be squared with the Due Process Clause of the Fifth Amendment. ${ }^{23}$ Accordingly, given the degree to which the State Department's approach contravenes those constitutional guarantees, the State Department's practice constitutes invidious discrimination against U.S. citizens and must cease.

This Article proceeds in four parts. Part I focuses on the ways in which the INA currently permits parents to transmit their citizenship to children born abroad, and yet, the State Department's interpretation of "out of wedlock" is at odds with that statutory scheme. Part II explores the two fundamental rights implicated by the State Department's approach to denying citizenship rights of the nonbiological children of same-sex marriage who are born abroad: the right to marry and the right to parent. Part III, in turn, argues that the discriminatory approach taken by the State Department is, in addition to not being entitled to Chevron deference, a violation of those constitutional guarantees. Finally, this Article concludes by offering some thoughts on the larger constitutional and policy implications raised by this issue.

\section{Parenthood and the Conferral of Citizenship UNDER THE INA}

As the Supreme Court has recognized, "There are 'two sources of citizenship, and two only: birth and naturalization.'" 24 In terms of birthright citizenship, which is the focus of this Article, the Fourteenth Amendment provides that a child born in the United States automatically receives American citizenship. ${ }^{25}$ This conferral of citizenship, re-

20 Obergefell, $135 \mathrm{~S}$. Ct. at 2590.

21 See 8 U.S.C. $\$ 1401$ (2012); see also infra notes 43-44 and accompanying text.

22 See infra Section II.B.

23 See infra Section III.B.2.

24 Miller v. Albright, 523 U.S. 420, 423 (1998) (quoting United States v. Wong Kim Ark, 169 U.S. 649, 702 (1898)).

25 U.S. Const. amend. XIV, § 1 ("All persons born or naturalized in the United States ... are citizens of the United States and of the State wherein they reside.”). 
ferred to as jus soli, ${ }^{26}$ happens regardless of the citizenship status of the child's parents. ${ }^{27}$ The Fourteenth Amendment, however, is not the only way in which one acquires United States citizenship. As Justice Breyer noted in dissent in Miller v. Albright, 28 "Since the founding of our Nation, American statutory law, reflecting a long-established legal tradition, has provided for the transmission of American citizenship from parent to child-even when the child is born abroad."29 Justice Breyer was referring to the practice of jus sanguinis or the "acquisition of citizenship by descent ... [whereby] children . . . acquire the nationality of their parents even though born outside the national territory." ${ }^{30}$ Statutes governing the way in which American citizens transmit citizenship to their children are found in the INA. ${ }^{31}$ Thus, for children born outside the United States, one must consult those provisions to determine whether that person qualifies as a "child" and, if so, what the specific requirements are for inheriting U.S. citizenship.

As an initial matter, the INA provides a rather lengthy definition of "child." ${ }_{32}$ At its heart, however, is the requirement that one must be "an unmarried person under twenty-one years of age" to qualify. ${ }^{33}$ Other portions of the definition make clear that the term can encompass adopted children, ${ }^{34}$ nonmarital children, ${ }^{35}$ and even stepchildren. ${ }^{36}$ The definition of "parent," however, is much shorter given that the term is simply defined in reference to the earlier definition of child: "The terms 'parent', 'father', or 'mother' mean a parent, father, or mother only where the relationship exists by reason of any of the circumstances set forth in [the INA's definition of 'child']." ${ }^{37}$ In other words, the INA seems to apply a plain-language approach to defining

26 David A. Martin, New Rules on Dual Nationality for a Democratizing Globe: Between Rejection and Embrace, 14 Geo. Immigr. L.J. 1, 5 n.11 (1999) ("Jus soli refers to the acquisition of citizenship based on birth in the territory.").

27 See, e.g., Wong Kim Ark, 169 U.S. at 693.

28523 U.S. 420 (1998).

29 Id. at 471 (Breyer, J., dissenting).

30 Martin, supra note 26, at 5 n.11.

31 See 8 U.S.C. $\$ 1401$ (2012).

32 See id. §1101(b).

33 Id. $\S 1101(\mathrm{~b})(1)$.

$34 \quad$ Id. $\S 1101(\mathrm{~b})(1)(\mathrm{E})$.

35 Id. $\S 1101(\mathrm{~b})(1)(\mathrm{D})$.

36 Id. $\S 1101(\mathrm{~b})(1)(\mathrm{B})$.

37 Id. $§ 1101$ (b)(2); see Fiallo v. Bell, 430 U.S. 787, 789 (1977) (“[A] person qualifies as a 'parent' for purposes of the Act solely on the basis of the person's relationship with a 'child."' (citation omitted)). 
"parent" but only when the "child" in question fulfills the much more narrow definition of that term. ${ }^{38}$

To understand when a child born abroad inherits American citizenship, one must look to INA sections 301 and 309. ${ }^{39}$ INA section 301 identifies those who "shall be nationals and citizens of the United States." 40 The first category is "a person born in the United States," ${ }^{11}$ thus reaffirming the citizenship clause of the Fourteenth Amendment. For those born outside the United States, questions of citizenship turn on several considerations, including where exactly the child was born, the citizenship status of the parents, and the amount of time the citizen parent(s) spent in the United States..$^{42}$ For instance, a child born abroad to parents who are both American citizens will receive U.S. citizenship so long as prior to the child's birth either parent "had a residence in the United States or one of its outlying possessions." 43 If, however, only one parent is an American citizen, the child will only receive U.S. citizenship if the citizen parent, prior to the birth of the child, "was physically present in the United States or its outlying possessions for a period or periods totaling not less than five years, at least two of which were after attaining the age of fourteen years." ${ }_{44}$

For nonmarital children, the rules become even more complicated. In those instances, one must look to INA section 309, titled "Children born out of wedlock." 45 Under those provisions, a nonmarital child born outside the United States can claim citizenship through an American father, but only if established that the father (1) had a "blood relationship" with the child, (2) agreed in writing to support the child until the child reaches the age of majority, and (3) took certain steps to legitimate or acknowledge the child while the child was still under the age of eighteen. ${ }^{46}$ In addition, the father also

38 See Kathleen Ja Sook Bergquist, Right to Define Family: Equality Under Immigration Law for U.S. Inter-Country Adoptees, 22 Geo. Immigr. L.J. 1, 12 (2007) (noting that when it comes to definition of "parent," the INA defines it "in a circular manner by referencing the definition of child").

39 See 8 U.S.C. $\S \S 1401,1409$ (2012).

40 Id. $\S 1401$.

41 Id. § 1401(a).

42 Id. $\$ 1401(\mathrm{c})-(\mathrm{e})$.

$43 I d . \S 1401(\mathrm{c})$.

$44 I d$. $\$ 1401$ (g). If, however, the child is born not abroad, but in an "outlying possession of the United States," the child acquires citizenship of an American parent so long as the parent, prior to the child's birth, "has been physically present in the United States or one of its outlying possessions for a continuous period of one year." Id. § 1401(e).

45 Id. $\$ 1409$.

46 Id. $\S 1409(\mathrm{a})(1)-(4)$. 
has to comply with the residency requirements of INA section $301 .{ }^{47}$ In contrast, if a nonmarital child born abroad seeks citizenship through an American mother, it need only be established that the mother spent the requisite amount of time in the United States. ${ }^{48}$

Although INA section 309 only applies to children born "out of wedlock," nowhere in the INA is that phrase defined. As the Supreme Court has pointed out, "A fundamental canon of statutory construction is that, unless otherwise defined, words will be interpreted as taking their ordinary, contemporary, common meaning." ${ }^{49}$ Thus, one would assume that Congress, by using but not defining the term "out of wedlock," intended that the traditional meaning of the phrase would apply. Ordinarily, to say that a child was born "out of wedlock" would mean that the child was born to unwed parents ${ }^{50}$-a class of children once referred to as "illegitimate." 51 Indeed, when interpreting the meaning of INA section 309, courts have applied this ordinary meaning, holding that the "blood relationship" requirement is inapplicable when at the time of the child's birth the legal parents were, in fact, married.

For example, in Solis-Espinoza v. Gonzales, ${ }^{22}$ the Ninth Circuit was asked to decide the citizenship status of Eduardo Solis-Espinoza, who was born in Mexico in 1967 to two Mexican nationals. ${ }^{53}$ Compli-

47 Id. $\$ 1409$ (a) ("The provisions of [INA section 301] shall apply as of the date of birth to a person born out of wedlock ....").

48 Id. $\$ 1409$ (c). Although INA section 309's requirements vary based on the gender of the citizen parent, the Supreme Court has rejected claims that the statute constitutes impermissible gender discrimination. See Nguyen v. INS, 533 U.S. 53, 73 (2001) ("The difference between men and women in relation to the birth process is a real one, and the principle of equal protection does not forbid Congress to address the problem at hand in a manner specific to each gender.").

49 Perrin v. United States, 444 U.S. 37, 42 (1979); see Smith v. United States, 508 U.S. 223, 242 (1993) (Scalia, J., dissenting) ("In the search for statutory meaning, we give nontechnical words and phrases their ordinary meaning.").

50 See Recent Development, Child Conceived by A.I.D. is Illegitimate but Consenting Husband Held Liable for Support, 64 Colum. L. REv. 376, 376-79 (1964) (noting that "[a]t common law a bastard or illegitimate was defined as one born out of wedlock").

51 See, e.g., Vincent v. Sutherland, 691 P.2d 85, 87-88 (Okla. Civ. App. 1984) ("The very idea of tarnishing the innocence of a new born miracle of creation with the descriptive term 'illegitimate' is an ecclesiastical anachronism that is generally recognized today as an anathema."); Sola v. Clostermann, 679 P.2d 317, 318 n.2 (Or. Ct. App. 1984) (noting that Oregon law uses the term "child born out of wedlock" because "[c]hildren are neither legitimate nor illegitimate, but are only children.”); Carolyn S. Bratt, A Primer on Kentucky Intestacy Laws, 82 Ky. L.J. 29, 70 (1994) (noting that at least one state had "amended its statutes to remove all reference to 'legitimate,' 'illegitimate,' 'bastards,' or similar terms and substituted the less pejorative terms 'born in wedlock' and 'born out of wedlock'").

52401 F.3d 1090 (9th Cir. 2005).

53 Id. at 1091 ("Solis-Espinoza's biological mother, . . . a Mexican citizen, . . . abandoned him.”). 
cating the issue, however, was the fact that when Solis-Espinoza was born, his father was married to an American citizen, Stella Cruz-Dominguez. ${ }^{54}$ His father, who was a lawful permanent resident of the United States, and Cruz-Dominguez, whom California law treated as the child's legal mother, subsequently raised Solis-Espinoza in the United States. ${ }^{55}$ In 2001, Solis-Espinoza was convicted of drug possession, and the INS sought to remove him from the United States. ${ }^{56}$ Solis-Espinoza claimed, however, that he had inherited U.S. citizenship through Cruz-Dominguez, his legal mother, and thus he could not be removed..$^{57}$ The INS countered that "because his biological father was not married to his biological mother at the time of his birth," INA section 309 was the applicable provision.58 Accordingly, "[s]ince neither of Solis-Espinoza's biological parents were United States citizens, he did not share a blood relationship with a U.S. citizen and did not . . . qualify for citizenship." 59

The Ninth Circuit, however, rejected this interpretation, holding that the "blood relationship" requirement of INA section 309 only applied to nonmarital children, which Solis-Espinoza clearly was not. ${ }^{60}$ As the court pointed out, California law "provided specifically that a child, such as Solis-Espinoza, who was acknowledged by the father and accepted into the family by the father's wife, was legitimate." 61 Accordingly, "Cruz-Dominguez was petitioner's mother and he was her son." 62 In support of its conclusion, the court noted that the INA "was intended to keep families together. It should be construed in favor of family units and the acceptance of responsibility by family members." 63

Notably, Solis-Espinoza was not the first case to reach this conclusion. Five years earlier, in Scales $v$ INS,$^{64}$ the Ninth Circuit ruled

55 Id. at 1091-92 ("Cruz-Dominguez accepted the infant as her own child, and the couple raised him to adulthood as part of their family. Indeed, Cruz-Dominguez is listed as Solis-Espinoza's mother on his birth certificate, although petitioner concedes that she is not his biological mother.").

56 Id. at 1092.

57 Id.

58 Id.

59 Id.

60 Id. at 1094.

61 Id. at 1093-94 (citing CAL. Civ. Code $\$ 230$ (1888)).

62 Solis-Espinoza, 401 F.3d at 1094. ("Under the law of California at the relevant time, therefore, Solis-Espinoza was 'for all purposes legitimate' from the time of his birth.”).

63 Id. ("There is no good reason to treat petitioner otherwise. Public policy supports recognition and maintenance of a family unit.").

64232 F.3d 1159 (9th Cir. 2000).
} 
that Stanley Scales had likewise acquired U.S. citizenship at birth and, thus, could not be deported. ${ }^{65}$ In that case, Scales was born in the Philippines. ${ }^{66}$ Prior to his birth, Scales's mother, who was a Philippine citizen, had married a U.S.-citizen serviceman. ${ }^{67}$ It is unlikely that her husband was Scales's biological father, and in fact, when the family subsequently came to the United States, her husband submitted an affidavit of nonpaternity. ${ }^{68}$ The family settled in Washington where the law regarded Scales as the legal child of the U.S. citizen whom Scales's mother had married prior to his birth. ${ }^{69}$ Further, as the court noted, "There is nothing in the record to indicate that [the U.S. citizen father] has ever treated [Scales] as other than his own son." "70

Nonetheless, when Scales was subsequently convicted of a controlled substances violation, the INS sought to deport him. ${ }^{71}$ Scales argued, however, that he had acquired U.S. citizenship at birth and thus was not subject to deportation. ${ }^{72}$ The INS countered by arguing that because his legal parents were not his biological parents, Scales was born "out of wedlock" and thus could only prevail by showing a "blood relationship" with his U.S. citizen parent. ${ }^{73}$ The court, however, rejected this argument:

The statutory provisions concerning citizenship do not address the situation presented here, where the child is "legitimate" by virtue of his parents being married at the time of his birth, yet he may not be the "natural," or biological, child of the citizen parent. [INA section 301] merely states that a person "born ... of parents one of whom is an alien, and the other a citizen of the United States" is a citizen, if

65 Id. at $1160-61$.

66 Id. at 1161.

67 Id. at 1161-62. One week after meeting her future husband, Scales's mother told him that she was pregnant, "probably from a prior relationship." Id. at 1162.

68 Id. ("In the affidavit, [Scales's father] stated that he was not Petitioner's natural father, that his wife was pregnant at the time she and [Scales's father] met, and that he 'accept[ed] [Petitioner] as [his] own son in every legal sense permissible, but . . . did not make any attempts of making a claim for U.S. citizenship for him at this time or at any other time.'" (third, fourth, fifth, and sixth alterations in original)).

69 Id. at $1163 \mathrm{n} .7$ ("[A] man is presumed to be the natural father of a child if ... [h] e and the child's natural mother are or have been married to each other and the child is born during the marriage." (quoting Wash. Rev. Code $\$ 26.26 .040(1)(a)$ (amended 1989))).

70 Scales, 232 F.3d at 1162.

71 See id.

72 See id.

73 Id. ("The [Board of Immigration Appeals] reasoned that, in order 'to acquire United States citizenship at birth there must be a blood relationship between the child and the parent through whom citizenship is claimed'...." (citation omitted)). 
the residency requirement is met by the citizen parent. A straightforward reading of [INA section 301] indicates, however, that there is no requirement of a blood relationship....

[INA section 309] does expressly require a blood relationship between a person claiming citizenship and a citizen father, if the person is born out of wedlock. This provision does not apply to Petitioner, however, because he was born to parents who were married at the time of his birth. ${ }^{74}$

The court also pointed out that

[INA section 309] clearly was enacted, "at least in part, to ensure that a person born out of wedlock who claims citizenship by birth actually shares a blood relationship with an American citizen." If Congress had wanted to ensure the same about a person born in wedlock, "it knew how to do so." 75

Despite this reasoning and despite the absence of any statutory definition of "out of wedlock" within the INA, the State Department is currently treating children who are the legal children of married same-sex parents as nonetheless being born "out of wedlock." 76 The State Department attempts to justify this approach by relying upon a definition contained not in any statute, but in an appendix to its Foreign Affairs Manual. The definition in question provides that "[ $t$ ]o say a child was born 'in wedlock' means that the child's biological parents were married to each other at the time of the birth of the child."77 It further provides that "[i]f a married woman and someone other than her spouse have a biological child together, that child is considered to have been born out of wedlock. The same is true for a child born to a married man and a person other than his spouse."78 It is this definition-a definition that is not the product of notice-and-comment rulemaking - that has provided the basis for denying citizenship claims of children of same-sex marriages, like Ethan Dvash-Banks, discussed earlier. ${ }^{79}$

Ethan, however, is not the only child of same-sex parents who has had his citizenship application denied on this basis. Consider, for instance, the case of Lucas Alexander Zaccari-Blixt. ${ }^{80}$ Lucas is a two-

74 Id. at 1164 (footnote omitted) (citation omitted).

75 Id. (citation omitted).

76 See supra Introduction.

77 See U.S. Dep't of State, supra note 14, § 1140 app. E, c.

78 Id. $\$ 1140$ app. E, e.

79 See supra note 2 and accompanying text.

80 The details of the Zaccari-Blixt family's attempt to have the government recognize the 
year-old child whose parents are Allison Blixt and Stefania Zaccari, a lesbian couple who met in $2006 .{ }^{81}$ Blixt is an American citizen, while Zaccari is a citizen of Italy. ${ }^{82}$ In 2008 , Blixt and Zaccari both moved to London, where ultimately they were married. ${ }^{83}$ Desiring to start a family, both women became pregnant, via artificial insemination, with sperm from the same anonymous donor ${ }^{84}$ Zaccari gave birth to Lucas, and Blixt gave birth to another son named Massi. ${ }^{85}$ Blixt and Zaccari are listed as parents on each boy's birth certificate. ${ }^{86}$

Subsequently, the couple, relying upon Blixt's status as an American citizen, attempted to secure U.S. passports for their two boys. ${ }^{87}$ Massi's application was granted, but Lucas's was denied..$^{88}$ Once again, the government relied on the State Department's definition and treated the two boys as being born "out of wedlock." 89 Thus, despite the fact that both boys were born into a legal marriage, only Massi qualified for U.S. citizenship, given that he was the only child who had a biological relationship with the American-citizen mother. Both families, the Zaccari-Blixts and the Dvash-Banks, are currently challenging the State Department's ruling..$^{90}$

\section{Same Sex Marriage, Parental Rights, AND THE CONSTITUTION}

The Fifth Amendment provides that "[n]o person shall be ... deprived of life, liberty, or property, without due process of law." ${ }^{91}$ In interpreting that clause-as well as its counterpart in the Fourteenth

citizenship status of their children are all taken from the complaint filed on their behalf by Immigration Equality. See generally Complaint, Blixt v. Tillerson, No. 1:18-cv-00124 (D.D.C. Jan. 22, 2018), https://www.immigrationequality.org/wp-content/uploads/2018/01/Blixt-Complaint-Filed .pdf [https://perma.cc/A94H-NXMC].

81 See id. at 4, 11.

82 Id. at 1.

83 Id. at 12. The couple moved to London because at that time same-sex marriage was not legal in the United States. See Christianna Silva, State Department Sued for Denying Citizenship to Children of Binational Same-Sex Couples, Newsweek (Jan. 22, 2018), http://www.newsweek .com/state-department-sued-denying-citizenship-children-binational-same-sex-couples-787473 [https://perma.cc/BUC3-9BCL].

84 Complaint at 1-2, 13, Blixt, No. 1:18-cv-00124.

85 Id. at $1-2$.

86 Id.

87 Id. at 14.

88 Id. at 14-15.

89 Id. at 2.

90 See Sacchetti, supra note 12.

91 U.S. CONST. amend. V. 
Amendment ${ }^{92}$ - the Court has interpreted the term "liberty" quite broadly. As the Court stated in Bolling v. Sharpe ${ }^{93}$ in which the Court held that racial segregation in schools in the District of Columbia violated the Due Process Clause of the Fifth Amendment,

Although the Court has not assumed to define "liberty" with any great precision, that term is not confined to mere freedom from bodily restraint. Liberty under law extends to the full range of conduct which the individual is free to pursue, and it cannot be restricted except for a proper governmental objective. ${ }^{94}$

Thus, the Due Process Clause "guarantees more than fair process." 95 Instead, "[t]he Clause also includes a substantive component that 'provides heightened protection against government interference with certain fundamental rights and liberty interests." "'96

Further, when dealing with the fundamental rights of American citizens, those rights receive the same constitutional protection even when arising in the context of immigration law, over which Congress typically has greater legislative authority. ${ }^{97}$ It is true that the Court "has been reluctant to frame immigration questions in terms of the rights of affected U.S. citizens." 98 One obvious example would be the 1977 case of Fiallo v. Bell, ${ }^{99}$ where the Court confronted a provision of the INA that gave an immigration preference to nonmarital children of female citizens but not male citizens. ${ }^{100}$ The Court upheld the law, holding that "the congressional decision not to accord preferential status to this particular class of aliens ... remains one 'solely for the

\footnotetext{
92 U.S. Const. amend. XIV, $\S 1$ ("No State shall . . . deprive any person of life, liberty, or property, without due process of law ....”).

93347 U.S. 497 (1954).

94 Id. at $499-500$.

95 Washington v. Glucksberg, 521 U.S. 702, 719 (1997).

96 Troxel v. Granville, 530 U.S. 57, 65 (2000) (plurality opinion) (quoting Glucksberg, 521 U.S. at 720$)$.

97 See Soraya Fata et al., Custody of Children in Mixed-Status Families: Preventing the Misunderstanding and Misuse of Immigration Status in State-Court Custody Proceedings, 47 FAm. L.Q. 191, 218 (2013) ("All parents have a fundamental right to raise their child, and immigration status should not preclude this fundamental right."); David B. Thronson, Choiceless Choices: Deportation and the Parent-Child Relationship, 6 Nev. L.J. 1165, 1197 (2006) ("[F]undamental rights in the parent-child relationship are not weakened by parents' lack of immigration status or even their imminent deportation.").

98 Jessica Portmess, Comment, Until the Plenary Power Do Us Part: Judicial Scrutiny of the Defense of Marriage Act in Immigration After Flores-Villar, 61 Ам. U. L. Rev. 1825, 1864 (2012).

99430 U.S. 787 (1977)

100 Id. at 798.
} 
responsibility of the Congress and wholly outside the power of this Court to control." "101 Just recently, however, in 2017, the Court in Sessions v. Morales-Santana ${ }^{102}$ distinguished Fiallo, noting that it applied only in the narrow context of "entry preferences." 103 Accordingly, the Court held that Fiallo had no application to the facts of MoralesSantana given that the latter "involves no entry preference for aliens. [Instead,] Morales-Santana claims he is, and since birth has been, a U.S. citizen. Examining a claim of that order, the Court has not disclaimed, as it did in Fiallo, the application of an exacting standard of review." 104 In other words, "Fiallo concerned aliens who never had citizenship, whereas Luis Morales-Santana had citizenship at birth that is not subject to immigration laws." 105 Accordingly, MoralesSantana enjoyed full constitutional protections. ${ }^{106}$ Indeed, the Court went on in Morales-Santana to strike down a provision of the INA on the basis that it unconstitutionally discriminated against United States citizens on the basis of gender. ${ }^{107}$

Here, the State Department's interpretation of INA sections 301 and 309 likewise implicate fundamental rights of United States citizens-both the right to marry and the right to parent. Before analyzing how exactly the State Department's approach runs afoul of those constitutional guarantees, this Part provides a brief overview of these two rights at issue.

\section{A. The Fundamental Right to Marry}

In 1888, the Supreme Court stated that "[m]arriage, as creating the most important relation in life, [and] as having more to do with

101 Id. at 798-99 (quoting Harisiades v. Shaughnessy, 342 U.S. 580, 597 (1952)).

102137 S. Ct. 1678 (2017).

103 Id. at $1684,1693$.

104 Id. at $1693-94$.

105 Rick Zou, Note, Stateless in the United States: The United Nations' Efforts to End Statelessness and American Gender Discrimination in Lynch v. Morales-Santana, 90 S. CAL. L. REv. 85, 104 (2016); see Kerry Abrams, Family Reunification and the Security State, 32 Const. ComMENT. 247, 277 (2017) (noting that although Fiallo has not been explicitly overruled, its reasoning has been "substantially undermined").

106 Morales-Santana, 137 S. Ct. at 1698.

107 Id. at 1694-98. The Court struck down a separate provision in INA section 309, which required that U.S. citizen fathers must have lived in the United States for a longer period of time than U.S. citizen mothers in order to pass citizenship to their nonmarital children born abroad. See 8 U.S.C. $\$ \S 1401(\mathrm{~g}), 1409$ (a), (c) (2012). In ruling as it did, the Court held that "the Government has advanced no 'exceedingly persuasive' justification for $\S 1409$ (a) and (c)'s gender-specific residency [requirement]. Those disparate criteria, we hold, cannot withstand inspection under a Constitution that requires the Government to respect the equal dignity and stature of its male and female citizens." Morales-Santana, 137 S. Ct. at 1698. 
the morals and civilization of a people than any other institution, has always been subject to the control of the legislature." 108 Since that time, however, the Supreme Court has increasingly recognized that under the Due Process Clause of both the Fifth and Fourteenth Amendments, there are notable limits to the government's ability to regulate marriage. ${ }^{109}$ Specifically, the Court has declared that under the substantive component of the Due Process Clauses of those amendments, marriage is a fundamental right. ${ }^{110}$

Despite earlier references by the Court to the importance of marriage, ${ }^{111}$ it was not until the Court's 1967 decision in Loving v. Virginia $^{112}$ that the Court would explicitly rely on that right to strike down legislation-in that instance, Virginia's antimiscegenation law. ${ }^{113}$ The Court did so primarily on the basis that the statute at issue, which "prohibit[ed] only interracial marriages involving white persons," was designed to promote white supremacy and, thus, violated the Equal Protection Clause of the Fourteenth Amendment. ${ }^{114}$ Notably, however, the Court did not stop there but went on to hold that the statue at issue also ran afoul of the Due Process Clause. ${ }^{115}$ The Court did so by first noting that " $[\mathrm{t}]$ he freedom to marry has long been recognized as one of the vital personal rights essential to the orderly pursuit of happiness by free men." 116 The Court then held that "[t]o deny this fundamental freedom on so unsupportable a basis as the racial classifications embodied in these statutes, classifications so directly subversive of the principle of equality at the heart of the Fourteenth Amendment, is surely to deprive all the State's citizens of liberty without due process of law." 117

108 Maynard v. Hill, 125 U.S. 190, 206 (1888) (emphasis added).

109 See, e.g., United States v. Windsor, 570 U.S. 744, 771 (2013) (recognizing that the state interest in regulating marriage is limited by constitutional guarantees).

110 See infra notes 113-52 and accompanying text.

111 See, e.g., Skinner v. Oklahoma ex rel. Williamson, 316 U.S. 535, 541 (1942) (stating, in striking down Oklahoma's sterilization law, that "[m]arriage and procreation are fundamental to the very existence and survival of the race").

112388 U.S. 1 (1967).

113 See Roger J.R. Levesque, Child Maltreatment and the Law 46 (2008) (noting that prior to Loving, "the Court had yet to rule that marriage itself was a fundamental right deserving robust constitutional protection").

114 Loving, 388 U.S. at 11-12. In reaching this conclusion, the Court noted the state's proffered justifications of " 'preserv[ing] the racial integrity of its citizens,' and . . . prevent[ing] 'the corruption of blood,' 'a mongrel breed of citizens,' and 'the obliteration of racial pride.' Id. at 7 (citation omitted).

115 Id. at 12 .

116 Id.

117 Id. 
Since Loving, the Court has taken a number of opportunities to reaffirm its understanding of marriage as a fundamental right. For instance, the Court in Zablocki v. Redhail ${ }^{118}$ invalidated a Wisconsin statute prohibiting noncustodial parents who had been ordered to pay child support from obtaining a marriage license without court approval. ${ }^{119}$ Despite the state's interest in securing child support payments, the Court found that the law in question went too far. Indeed, those who were incapable of paying their child support obligation would be "absolutely prevented from getting married." 120 Additionally, for those who were "able in theory to satisfy the statute's requirements," they could nonetheless "be sufficiently burdened by having to do so that they will in effect be coerced into forgoing their right to marry." ${ }^{121}$ Subsequently, in Turner v. Safley, ${ }^{122}$ the Court invalidated a Missouri prison regulation that permitted "an inmate to marry only with the permission of the superintendent of the prison, and provide[d] that such approval should be given only 'when there are compelling reasons to do so." " 123 The Court ruled that the regulation in question was overinclusive and, thus, unconstitutional, noting that although "Missouri prison officials may regulate the time and circumstances under which the marriage ceremony itself takes place[,] ... the almost complete ban on the decision to marry is not reasonably related to legitimate penological objectives." 124

Whereas Turner, Zablocki, and Loving all dealt with state laws, in 2013 the Court would, in Windsor, strike down a federal law that sought to limit federal recognition of state marriages. ${ }^{125}$ The law in question was the Defense of Marriage Act ("DOMA"), which in relevant part provided,

In determining the meaning of any Act of Congress, or of any ruling, regulation, or interpretation of the various ad-

118434 U.S. 374 (1978)

119 Id. at 375.

120 Id. at 387. The facts of the case demonstrate why the state was so concerned: Redhail fathered a child while he was in high school, and at the time Redhail sought to obtain a marriage license, he had not only failed to satisfy his support obligations to the child, but "the child had been a public charge since her birth, receiving benefits under the Aid to Families with Dependent Children program." Id. at 378.

121 Id. at 387.

122482 U.S. 78 (1987).

123 Id. at 82 (citation omitted) ("The term 'compelling' is not defined, but prison officials testified at trial that generally only a pregnancy or the birth of an illegitimate child would be considered a compelling reason.").

124 Id. at 99.

125 See United States v. Windsor, 570 U.S. 744, 745 (2013). 
ministrative bureaus and agencies of the United States, the word "marriage" means only a legal union between one man and one woman as husband and wife, and the word "spouse" refers only to a person of the opposite sex who is a husband or a wife. ${ }^{126}$

As states began to permit same-sex marriage, DOMA was an attempt to ensure that the federal government would not have to recognize same-sex marriages for purposes of providing federal benefits. ${ }^{127}$

The case involved a lesbian couple, Edith Windsor and Thea Spyer, who had been involved with one another since $1963 .{ }^{128}$ The couple registered as domestic partners in 1993 and married in Canada in 2007. ${ }^{129}$ In 2009, Spyer died, leaving her estate to Windsor. ${ }^{130}$ In light of DOMA, Windsor could not take advantage of the marital exemption for federal estate tax and was thus forced to pay over $\$ 300,000$ in estate taxes - an amount she would not have had to pay had Spyer been male. ${ }^{131}$ Windsor challenged DOMA, and the Court agreed that the law was unconstitutional, characterizing it as violative of "basic due process and equal protection principles applicable to the Federal Government"132:

The class to which DOMA directs its restrictions and restraints are those persons who are joined in same-sex marriages made lawful by the State. DOMA singles out a class of persons deemed by a State entitled to recognition and protection to enhance their own liberty. It imposes a disability on the class by refusing to acknowledge a status the State finds to be dignified and proper. DOMA instructs all federal officials, and indeed all persons with whom same-sex couples interact, including their own children, that their marriage is less worthy than the marriages of others. ${ }^{133}$

\footnotetext{
1261 U.S.C. $\$ 7$ (2012).
}

127 See Scott Ruskay-Kidd, Note, The Defense of Marriage Act and the Overextension of Congressional Authority, 97 Colum. L. Rev. 1435, 1435 (1997) (noting how DOMA "grant[ed] states the right to ignore same-sex marriages contracted in other states, and create[d] a federal definition of marriage, which exclude[d] same-sex couples, to be applied in connection with all federal statutes and programs").

128 See Windsor, 570 U.S. at 753.

129 See id. Nonetheless, the couple continued to live in New York. See id.

130 See id.

131 Id. (noting that law "excludes from taxation 'any interest in property which passes or has passed from the decedent to his surviving spouse"” (quoting 26 U.S.C. § 2056(a) (2012))).

132 Id. at 746.

133 Id. at 775. 
In short, the Court held that "no legitimate purpose overcomes the purpose and effect to disparage and to injure those whom the State, by its marriage laws, sought to protect in personhood and dignity." 134 In so ruling, the Court noted that DOMA "humiliates tens of thousands of children now being raised by same-sex couples," and also that " $[\mathrm{t}]$ he law in question makes it even more difficult for the children to understand the integrity and closeness of their own family and its concord with other families in their community and in their daily lives." 135 Accordingly, the Court concluded that "[b]y seeking to displace this protection and treating those persons as living in marriages less respected than others, the federal statute is in violation of the Fifth Amendment."136

Two years later, in Obergefell v. Hodges, ${ }^{137}$ the Court would take up the larger question of whether a state may constitutionally prohibit same-sex marriage. ${ }^{138}$ Although the Court had previously held that "the right to marry is protected by the Constitution," 139 the precedent cases upon which that right had developed all involved laws that had clearly "presumed a relationship involving opposite-sex partners." 140 Nonetheless, according to Justice Kennedy's opinion, an analysis of those opinions "compels the conclusion that same-sex couples may exercise the right to marry." 141 Specifically, the Court identified four essential "principles and traditions" related to marriage that justify its classification as a fundamental right-principles and traditions that, according to the Court, "apply with equal force to same-sex couples." 142

First, citing Loving, the Court noted that "the right to personal choice regarding marriage is inherent in the concept of individual au-

\footnotetext{
134 Id.

135 Id. at 772. After Windsor was decided, other courts would begin to note the harms that same-sex marriage bans posed to children. See, e.g., Baskin v. Bogan, 766 F.3d 648, 654 (7th Cir. 2014) ("Formally these cases are about discrimination against the small homosexual minority in the United States. But at a deeper level, as we shall see, they are about the welfare of American children.").

136 Windsor, 570 U.S. at 775.

137135 S. Ct. 2584 (2015).

138 Id. at 2593.

139 Id. at 2598.

140 Id. at 2589. The Court had, in fact, previously issued a decision relating to same-sex couples and their right to marry. See Baker v. Nelson, 409 U.S. 810 (1972). In Baker, "a one-line summary decision issued in 1972," the Court held that "the exclusion of same-sex couples from marriage did not present a substantial federal question." Obergefell, 135 S. Ct. at 2598. Obergefell, of course, overruled Baker. Id. at 2605.

141 Obergefell, 135 S. Ct. at 2599.

142 Id.
} 
tonomy," 143 recognizing that "[t]here is dignity in the bond between two men or two women who seek to marry and in their autonomy to make such profound choices." ${ }^{144}$ Second, marriage is a fundamental right because the institution "supports a two-person union unlike any other in its importance to the committed individuals." 145 As the Court explained, "[Marriage] offers the hope of companionship and understanding and assurance that while both still live there will be someone to care for the other." 146

The Court looked to other fundamental rights, which in turn revealed that marriage "safeguards children and families and thus draws meaning from related rights of childrearing, procreation, and education." 147 Citing Windsor, where the Court noted how laws prohibiting same-sex marriage "harm and humiliate the children of same-sex couples," 148 the Court explained that "[b]y giving recognition and legal structure to their parents' relationship, marriage allows children 'to understand the integrity and closeness of their own family and its concord with other families in their community and in their daily lives." "149 Finally, in recognition of the fact that "marriage is a keystone of our social order," "150 the Court justified the fundamental nature of the right to marry, noting that marriage is "the foundation of the family and of society, without which there would be neither civilization nor progress." 151

Having distilled the right to marry down into those four components, each of which justifies its recognition as a fundamental right, the Court found no basis for excluding same-sex couples from that right:

Same-sex couples, too, may aspire to the transcendent purposes of marriage and seek fulfillment in its highest meaning.

\footnotetext{
143 Id.

144 Id. ("The nature of marriage is that, through its enduring bond, two persons together can find other freedoms, such as expression, intimacy, and spirituality.").

145 Id. "Marriage responds to the universal fear that a lonely person might call out only to find no one there." Id. at 2600.

146 Id. at 2600.

147 Id. (citing Pierce v. Soc'y of Sisters, 268 U.S. 510 (1925); Meyer v. Nebraska, 262 U.S. 390, 399 (1923)); see Kenji Yoshino, A New Birth of Freedom?: Obergefell v. Hodges, 129 Harv. L. Rev. 147, 164 (2015) (noting how Justice Kennedy's analysis is "studded with precedents, suggesting a jurist's common law approach to the question rather than a historian's approach to

148 Obergefell, $135 \mathrm{~S}$. Ct. at $2600-01$.

$149 I d$. at 2600 (quoting United States v. Windsor, 570 U.S. 744, 772 (2013)) ("Marriage also affords the permanency and stability important to children's best interests.").

$150 I d$. at 2601.

151 Id. (quoting Maynard v. Hill, 125 U.S. 190, 211 (1888)).
} it"). 
[Although the] limitation of marriage to opposite-sex couples may long have seemed natural and just, ... its inconsistency with the central meaning of the fundamental right to marry is now manifest. With that knowledge must come the recognition that laws excluding same-sex couples from the marriage right impose stigma and injury of the kind prohibited by our basic charter. ${ }^{152}$

Accordingly, the Court held that the Due Process Clause prohibits states from denying same-sex couples the ability to marry on terms equal to those of opposite-sex couples. ${ }^{153}$

\section{B. The Fundamental Rights of Parents}

The Supreme Court has observed that "[t]he history and culture of Western civilization reflect a strong tradition of parental concern for the nurture and upbringing of their children." 154 For that reason, the Court has long recognized that parents have a fundamental right to raise their children. In fact, in 2000, Justice O'Connor declared that "the interest of parents in the care, custody, and control of their children ... is perhaps the oldest of the fundamental liberty interests recognized by this Court." 155 Indeed, the Court has remarked that the "primary role of the parents in the upbringing of their children is now established beyond debate as an enduring American tradition."156 These constitutional protections include the "right to the care, custody and companionship of [the] child as well as the right to make decisions affecting the welfare of the child free from government interference, except in compelling circumstances." 157

152 Id. at 2602.

153 Id. at 2604-05.

154 Wisconsin v. Yoder, 406 U.S. 205, 232 (1972), overruled on other grounds by Emp't Div. v. Smith, 494 U.S. 872 (1990).

155 Troxel v. Granville, 530 U.S. 57, 65 (2000). Despite Justice O'Connor's characterization, however, the actual history behind the development of this right demonstrates that-unlike other rights traditionally considered "fundamental"-its status is far less certain. Id. at 92 (Scalia, J., dissenting) ("Only three holdings of this Court rest in whole or in part upon a substantive constitutional right of parents to direct the upbringing of their children - two of them from an era rich in substantive due process holdings that have since been repudiated." (footnote omitted)); see Jeffrey Shulman, The Constitutional Parent 8 (2014) (describing the right as "especially tenuous" and noting that "no Supreme Court holding supports this claim" that the right is truly fundamental).

156 Yoder, 406 U.S. at 232.

157 Katheryn D. Katz, Majoritarian Morality and Parental Rights, 52 Alb. L. Rev. 405, 406 (1988) (footnote omitted); see Prince v. Massachusetts, 321 U.S. 158, 166 (1944) ("It is cardinal with us that the custody, care and nurture of the child reside first in the parents, whose primary function and freedom include preparation for obligations the state can neither supply nor hinder."). 
Thus, the Due Process Clauses of the Fifth and Fourteenth Amendments protect the emotional bonds that exist between parent and child, effectively "prevent[ing] the state from seizing newborns and distributing them to parents by some administrative scheme." 158 What the Constitution does not do, however, is define "parent."159 That definition, then, must come from the Court, which has in fact issued five decisions on this topic-all of which center around the rights of nonmarital fathers. ${ }^{160}$ With those broad principles in mind, this Section attempts to chart the more specific contours of the fundamental right to parent, looking at both the nature and history of that right and also who qualifies as a parent for purposes of enjoying those constitutional safeguards.

\section{Parental Custody and Control}

The Supreme Court first recognized the fundamental rights of parents in Meyer v. Nebraska, ${ }^{161}$ a 1923 case involving a Nebraska statute that prohibited teaching "any subject to any person in any language other than the English language" regardless of whether the school in question was a "private, denominational, parochial or public school." ${ }^{62}$ The rationale behind the law, as laid out by the lower court

158 Jennifer S. Hendricks, Essentially a Mother, 13 WM. \& Mary J. Women \& L. 429, 454 (2007).

159 See Anthony Miller, The Case for the Genetic Parent: Stanley, Quilloin, Caban, Lehr, and Michael H. Revisited, 53 Loy. L. Rev. 395, 398 (2007) ("While the United States Supreme Court has established that the Constitution protects many parental rights, the Court has essentially left unresolved the issue of who qualifies as a parent."); see also Meyer, supra note 1, at 866 ("[W]hile the Constitution clearly protects 'parents' rights,' it does not clearly or necessarily say who a parent is."). The same can be said of many constitutional rights related to family privacy. As David Meyer has argued, "the Court has been content to let strands of doctrine emerge piecemeal. Rights to abortion, contraception, marriage, kinship, and the custody and rearing of children have, for the most part, sprung up independently of one another, only later converging into a loosely recognized constellation of 'family privacy' rights." David D. Meyer, The Paradox of Family Privacy, 53 VAND. L. Rev. 527, 528 (2000).

160 See Michael H. v. Gerald D, 491 U.S. 110, 131-32 (1989) (finding that a biological father who engages in an adulterous relationship with the child's mother does not have a constitutional right to paternity over the marital father); Lehr v. Robertson, 463 U.S. 248, 265, 267-68 (1983) (finding that states do not need to notify putative fathers with no established relationship with the child of the child's adoption); Caban v. Mohammed, 441 U.S. 380, 394 (1979) (finding that treating unwed mothers and unwed fathers differently regarding consenting to adoption violates Equal Protection Clause); Quilloin v. Walcott, 434 U.S. 246, 256 (1978) (upholding a state's decision to permit a stepparent adoption over the objections of an unwed father who refused to support the child); Stanley v. Illinois, 405 U.S. 645, 658-59 (1972) (declaring unconstitutional Illinois law that states that "children of unmarried fathers [are deemed to be] dependent children without a hearing on parental fitness and without proof of neglect").

161262 U.S. 390 (1923).

$162 I d$. at 396 (citation omitted). 
and adopted by the Supreme Court, was largely the anti-German xenophobia so prevalent during the post-World War I era. ${ }^{163}$

In considering the constitutionality of the challenged statute, the Court began by acknowledging that "this Court has not attempted to define with exactness the liberty thus guaranteed" under the Due Process Clause. ${ }^{164}$ Nonetheless, according to the Court, "[w]ithout doubt, it denotes not merely freedom from bodily restraint but also the right of the individual to," among other things, "establish a home and bring up children." 165 Despite this reference to the family, the Court treated the case as primarily one concerning language rights and, on that basis, struck down the law in question: "The protection of the Constitution extends to all, to those who speak other languages as well as to those born with English on the tongue." 166 Nonetheless, the Court's reference to parental rights would ultimately lead to Meyer being regarded as one of the foundational cases establishing the fundamental right of parents. ${ }^{167}$

Meyer would begin to earn that reputation just two years later, when the Court relied on it to support its holding in Pierce v. Society of Sisters. ${ }^{168}$ There, the Court was confronted with an Oregon statue that required all children to attend public school. ${ }^{169}$ The Society of Sisters, a private educational organization, brought suit on the grounds that

the enactment conflicts with the right of parents to choose schools where their children will receive appropriate mental and religious training, the right of the child to influence the parents' choice of a school, [and] the right of schools and teachers therein to engage in a useful business or profession. ${ }^{170}$

163 See id. at 398, 400-01. As the Court noted, "The obvious purpose of this statute was that the English language should be and become the mother tongue of all children reared in this state." Id. at 398. The Court also acknowledged that "the foreign born population is very large, that certain communities commonly use foreign words, follow foreign leaders, move in a foreign atmosphere, and that the children are thereby hindered from becoming citizens of the most useful type and the public safety is imperiled." Id. at 401.

164 Id. at 399.

165 Id.

166 Id. at 401. The Court noted that "[p]erhaps it would be highly advantageous if all had ready understanding of our ordinary speech, but this cannot be coerced by methods which conflict with the Constitution." Id.

167 See Meyer, supra note 159, at 533 (describing Meyer as one of "the foundational family privacy cases").

168268 U.S. 510, 534-35 (1925).

169 Id. at 530.

170 Id. at 532 . 
Just as it had done in Meyer, the Court struck down the challenged legislation. This time, however, the Court was more explicit in basing its ruling on parental rights, holding that the law in question "unreasonably interfere[d] with the liberty of parents and guardians to direct the upbringing and education of children under their control." 171 According to the Court, the Due Process Clause "excludes any general power of the State to standardize its children by forcing them to accept instruction from public teachers only." 172 Instead, in a now famous quote, the Court noted that parents retained the right to make such decisions on behalf of their children: "The child is not the mere creature of the State; those who nurture him and direct his destiny have the right, coupled with the high duty, to recognize and prepare him for additional obligations." ${ }^{173}$

Over the years, the Court would increasingly invoke Meyer and Pierce as evidence of its historical recognition of the fundamental rights of parents. In 1944, for instance, the Court in Prince v. Massachusetts $^{174}$ would rely on both cases when stating that

[i]t is cardinal with us that the custody, care and nurture of the child reside first in the parents, whose primary function and freedom include preparation for obligations the state can neither supply nor hinder. And it is in recognition of this that these decisions have respected the private realm of family life which the state cannot enter. ${ }^{175}$

Likewise, in 1997, the Court would again rely on the two cases when stating that

[i]n a long line of cases, we have held that . . the "liberty" specially protected by the Due Process Clause includes the rights to marry, to have children, to direct the education and upbringing of one's children, to marital privacy, to use contraception, to bodily integrity, and to abortion. ${ }^{176}$

In fact, the Court has gone so far as to characterize the "right to the care, custody, management and companionship" of one's children as being "far more precious . . . than property rights." 177

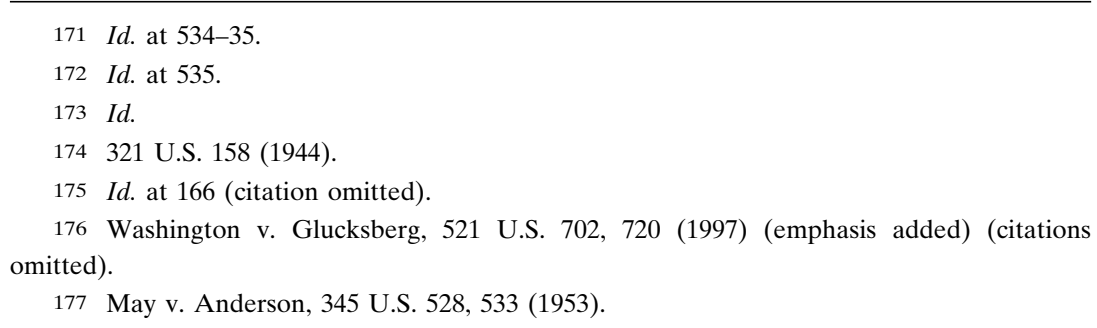




\section{Parental Identity}

As one noted scholar has pointed out, "while the Constitution clearly protects 'parents' rights,' it does not clearly or necessarily say who a parent is." 178 Although the Court has issued five opinions touching on the issue, the Court has never directly addressed the basic question of how parenthood must be defined for purposes of the Due Process Clause. ${ }^{179}$ Nonetheless, "it is the nature of a constitution to set outer limits to legislative competence." 180 And indeed, in analyzing the five cases, each of which center around the parental rights of nonmarital fathers, certain constitutional limitations do emerge on the question of just how restrictive the government can be in defining "parent." 181

It bears mention that Supreme Court cases dealing with parental identity, in contrast to parental rights, did not even arise until relatively recently. The reason for that delay is that, historically, parenthood flowed from marriage-the wife was recognized as the mother; her husband, the father. ${ }^{182}$ Given that in those years, in vitro fertilization did not exist, questions of motherhood never arose. Instead, the biological mother and the birth mother would have always been the same person. On the other hand, the absence of genetic testing meant that one could never be certain of the biological father's identity. The law, however, possessed a rather easy solution to that problem-it simply ignored biology and, instead, linked fatherhood to marriage. ${ }^{183}$ Referred to as "the marital presumption," the law simply

\footnotetext{
178 Meyer, supra note 1 , at 866.

179 See supra note 160 and accompanying text.

180 Marc A. Franklin, The Origins and Constitutionality of Limitations on Truth as a Defense in Tort Law, 16 Stan. L. Rev. 789, 798 (1964).

181 See infra note 228 and accompanying text.

182 See Janet L. Dolgin, Just a Gene: Judicial Assumptions About Parenthood, 40 UCLA L. REv. 637, 644 (1993) ("A child's mother was the woman who bore the child. Biology-including both genetics and the processes of pregnancy and birth-was paramount and decisive." (footnote omitted)); Hendricks, supra note 158, at 440 ("[T]raditionally, in the context of marriage, a father's rights derive from his relationship with the mother.").

183 See Michael Grossberg, Governing the Hearth: Law and the Family in NineTEENTH-CENTURy AMERICA 197 (1985) ("The law used matrimony to separate legal from spurious issue."); Miller, supra note 159, at 444 ("The law did not traditionally protect the rights of the genetic parent simply because the child's genetic parent could not be determined with certainty."); see also Dolgin, supra note 182, at 644 (noting that, historically, whereas "[n]ature identifie[d] mothers[,] . . fatherhood [could] only be presumed through a man's relation to the child's mother"). Further, this presumption was quite strong. See, e.g., WiLliam M. McGovern, JR. ET AL., Wills, Trusts, AND Estates 34-35 n.23 (1988) ("If a married woman gave birth to a child, her husband was held to be the child's father despite any evidence to the contrary. When a husband went abroad for three years and returned to find his wife with a month-old daughter,
} 
"assumed that married women did not bear children fathered by men other than their husbands." 184

For children born to women who were not married, parenthood was likewise quite easy to determine-the law simply viewed them as orphans. Considered "filius nullius," or "the child .. . of no one," illegitimate children had no legal relationship to either parent. ${ }^{185}$ Starting in the late 1960s, however, the Supreme Court would begin striking down laws that discriminated against nonmarital children. ${ }^{186}$ As a consequence, novel issues of paternity began to arise, forcing states to address an issue they had essentially never before had to consider: who qualifies as a parent. Specifically, because the law could no longer look to marriage to determine parentage, new means of identification were required. For nonmarital mothers, identification was quite simple- "The evidence of pregnancy and childbirth was irrefutable."187 When it came to identifying nonmarital fathers, however, the task was not so easy given that, in contrast to the mother's nine month gestation, "[o]nce a man has contributed genetic material, his biological task is essentially complete." 188 Thus, there was nothing as obvious as pregnancy or birth to provide assurances as to the identity of a child's father, nor, at that time, was genetic testing an available option. ${ }^{189}$ To the states, then, nonmarital fathers presented quite a challenge. Of course, even if a state could identify the biological father, questions

the law deemed the daughter to be the husband's child because 'the privity between a man and his wife cannot be known."”).

184 Dara E. Purvis, The Origin of Parental Rights: Labor, Intent and Fathers, 41 FLA. ST. U. L. Rev. 645, 662 (2014).

185 See Dorothy E. Roberts, The Genetic Tie, 62 U. Chi. L. Rev. 209, 253 \& n.183 (1995); see also John Dewey, The Historic Background of Corporate Legal Personality, 35 YALE L.J. 655, 656 (1926) ("[I]t was not understood to deny the fact of physiological begetting; it was asserting that such a one did not possess the specific rights which belong to one who was filius, implying wedlock as a legal institution.").

186 See, e.g., Trimble v. Gordon, 430 U.S. 762, 765-66 (1977) (striking down an Illinois statute that barred children from inheriting via intestacy from a nonmarital father); Weber v. Aetna Casualty \& Surety Co., 406 U.S. 164, 165 (1972) (striking down a Louisiana worker's compensation statute that discriminated on the basis of legitimacy); Levy v. Louisiana, 391 U.S. 68, 72 (1968) (striking down a Louisiana statute that prevented nonmarital children from bringing an action for the wrongful death of their mother).

187 Dolgin, supra note 182, at 644.

188 Sherry F. Colb, Words that Deny, Devalue, and Punish: Judicial Responses to FetusEnvy?, 72 B.U. L. Rev. 101, 103 (1992).

189 See Thomas H. Murray \& Ross S. White, Genetic Privacy in the United States: Exceptionalism, GINA, and the Future of Genetic Testing, in Genetic Privacy 253, 255 (Terry Sheung-Hung Kaan \& Calvin Wai-Loon Ho eds., 2013) (noting that the use of genetic testing to determine paternity did not emerge until the 1980s). 
remained as to what rights he would be entitled to and whether biology alone would trigger those rights.

In 1972, the Court would issue its first of five opinions dealing with the rights of nonmarital fathers. In Stanley v. Illinois, ${ }^{190}$ the Supreme Court invalidated a state law declaring that "the children of unwed fathers become wards of the State upon the death of the mother." ${ }^{191}$ When the mother of Peter Stanley's three nonmarital children died, he never received a hearing to prove that he was a fit parent because the state simply did not regard individuals like him as parents: "'Parents,' says the State, 'means the father and mother of a legitimate child, or the survivor of them; or the natural mother of an illegitimate child, and includes any adoptive parent,' but the term does not include unwed fathers." ${ }^{192}$ In striking down the law, the Court first noted that a father's interest in the "companionship, care, custody, and management" of his children is "cognizable and substantial." 193 The Court went on to find that, in terms of his due process argument, the interests put forward by the state were insufficient to overcome the liberty interest of a father in his children. ${ }^{194}$ Additionally, the Court found that the law also violated the Equal Protection Clause given that Illinois did in fact afford hearings to "married parents, divorced parents, and unmarried mothers." 195 According to the Court, "To say that the test of equal protection should be the 'legal' rather than the biological relationship is to avoid the issue. For the Equal Protection Clause necessarily limits the authority of a State to draw such 'legal' lines as it chooses." 196

Although the Court's opinion in Stanley might suggest that constitutional parenthood flows directly from biological parenthood, the Court's 1978 decision in Quilloin v. Walcott ${ }^{197}$ would prove otherwise. There, a biological father attempted to veto the adoption of his nonmarital child by the child's stepfather, who had married the

190405 U.S. 645 (1972).

191 Id. at 646.

192 Id. at 650 (quoting Ill. Rev. StAT. ch. 37, § 701-14 (1967) (amended version available at 705 Ill. Comp. Stat. 405/1-3(11) (2018)))

193 Id. at 651-52.

194 See id. at 658 ("[The state] insists on presuming rather than proving Stanley's unfitness solely because it is more convenient to presume than to prove. Under the Due Process Clause that advantage is insufficient to justify refusing a father a hearing when the issue at stake is the dismemberment of his family.").

195 Id. at 658.

196 Id. at 652 (quoting Glona v. Am. Guarantee Co., 391 U.S. 73, 75-76 (1968))

197434 U.S. 246 (1978). 
mother after the child was born. ${ }^{198}$ Because Georgia law only required the mother's consent, the biological father's objections were without legal effect, and the stepfather's adoption petition was granted. ${ }^{199}$ The Court ruled that in such instances, the state could constitutionally treat biological fathers differently from other fathers. ${ }^{200}$ Specifically, the biological father in that case had "never exercised actual or legal custody over his child, and thus ha[d] never shouldered any significant responsibility with respect to the daily supervision, education, protection, or care of the child." ${ }^{201}$ As such, the Court held that Georgia "was not foreclosed from recognizing this difference in the extent of commitment" to the welfare of the child. ${ }^{202}$

Just one year later, in Caban v. Mohammed, ${ }^{203}$ the Court ruled that a New York adoption statute, which required the consent of nonmarital mothers but not nonmarital fathers, was unconstitutional as applied to the facts of that case. ${ }^{204}$ As an initial matter, the Court was troubled by the degree to which the law in question discriminated on the basis of gender-a "claim [that] was not properly presented"205 in Quilloin. Further, turning to the facts of the case, the Court noted that, unlike the nonmarital father in Quilloin, Mr. Caban had "manifested a significant paternal interest in the child" both by living with and supporting his two children. ${ }^{206}$ Thus, as Professor Janet Dolgin describes it, "Caban suggests that a biological father's paternal behavior will determine the degree of protection the Constitution provides in safeguarding his relationship with his biological child."207

In 1983, the Court issued its fourth father's rights case, Lehr v. Robertson, ${ }^{208}$ where it attempted to synthesize the three previous

\footnotetext{
198 Id. at 247.

199 Id. at 248 ("[O]nly the consent of the mother is required for adoption of an illegitimate child.").

200 Id. at 256.

201 Id.

202 Id. For similar reasons, the Court found no violation of the Due Process Clause, noting that "this is not a case in which the unwed father at any time had, or sought, custody of his child." Id. at 255.

203441 U.S. 380 (1979).

204 Id. at 394.

205 Id. at 389 n.7. As the Court explained in Quilloin, "In the last paragraph of his brief, appellant raises the claim that the statutes make gender-based distinctions that violate the Equal Protection Clause. Since this claim was not presented in appellant's jurisdictional statement, we do not consider it." 434 U.S. at 253 n.13.

206 Caban, 441 U.S. at 394.

207 Dolgin, supra note 182, at 657.

208463 U.S. 248 (1983).
} 
holdings. ${ }^{209}$ Jonathan Lehr was a nonmarital father who, pursuant to state law, had not received notice of his daughter's impending stepparent adoption. ${ }^{210}$ Despite the fact that Lehr had played little role in his daughter's life, ${ }^{211}$ he challenged the adoption "on the ground that it was obtained by fraud and in violation of his constitutional rights."212 The Court held, however, that "the mere existence of a biological link does not merit equivalent constitutional protection." 213 Instead, the Court put forth what is commonly referred to today as the "biology plus" doctrine. ${ }^{214}$ According to the Court, "When an unwed father demonstrates a full commitment to the responsibilities of parenthood by 'com[ing] forward to participate in the rearing of his child,' his interest in personal contact with his child acquires substantial protection under the Due Process Clause." 215 In other words, biological parenthood provides a nonmarital father with a nascent right, one that will not fully develop until he takes sufficient steps to foster a parental relationship with the child. Accordingly, the Court upheld the New York law given that it "ha[d] adequately protected his opportunity to form such a relationship." 216

Six years later, the Court would issue its final father's right case in Michael H. v. Gerald D. ${ }^{217}$ - a case that seemingly departed from Lehr, calling into question the precise reach of the biology plus doctrine. ${ }^{218}$ The case concerned a biological father, Michael H., who fathered a child with a married woman. ${ }^{219}$ When she later reconciled with her husband, she refused to let Michael $\mathrm{H}$. see the child despite

209 Id. at $258-60$.

210 Id. at 250.

211 Id. at 252 ("He did not live with [the biological mother] or Jessica after Jessica's birth, he has never provided them with any financial support, and he has never offered to marry [the biological mother].").

212 Id. at 253.

213 Id. at 261.

214 See Daniel C. Zinman, Note, Father Knows Best: The Unwed Father's Right to Raise His Infant Surrendered for Adoption, 60 Fordham L. Rev. 971, 972 (1992) (using the phrase "biology plus" to describe the Court's test).

215 Lehr, 463 U.S. at 261 (alteration in original) (citations omitted) (quoting Caban v. Mohammed, 441 U.S. 380, 392 (1979)).

216 Id. at 263. The Court likewise rejected Lehr's Equal Protection argument for this same reason, finding that he and the mother were not similarly situated: "If one parent has an established custodial relationship with the child and the other parent has either abandoned or never established a relationship, the Equal Protection Clause does not prevent a State from according the two parents different legal rights." Id. at 267-68 (footnote omitted).

217491 U.S. 110 (1989).

218 Id. at 129.

219 Id. at $114-15$. 
the fact he had played a significant role in the child's life. ${ }^{220}$ In response, Michael filed an action in California to establish his paternity and to gain formal visitation. ${ }^{221}$ Unfortunately for him, California law provided that "the [child] of a wife cohabiting with her husband, who is not impotent or sterile, is conclusively presumed to be a child of the marriage." 222 Although one could rebut the presumption with genetic testing, such an action could only be brought within the first two years of the child's life and, even then, only by the husband or the wife. ${ }^{223}$

Relying on the Court's holding in Lehr, Michael H. argued that the law unconstitutionally infringed upon his substantive due process rights to maintain a relationship with his daughter. ${ }^{224}$ Under Lehr, his argument would appear to have some merit given that Michael was not only the biological parent, but he had also affirmatively acted as a parent for a significant part of her early life. Justice Scalia, however, in a plurality opinion, put forth an exception that denied Michael H.'s challenge: "Where ... the child is born into an extant marital family, the natural father's unique opportunity conflicts with the similarly unique opportunity of the husband of the marriage; and it is not unconstitutional for the State to give categorical preference to the latter." 225 Thus, despite Michael H.'s status as both the biological and the "social" father,226 the plurality held that his constitutional argument was without merit. ${ }^{227}$

Michael H. marked the final case in the father's rights cases. More importantly, it also marked the last time the Court would weigh in on who qualifies as a parent under the Due Process Clause. Although it can be somewhat difficult to synthesize the five opinions, ${ }^{228}$

220 Id. at 115. Justice Scalia famously began the plurality opinion with this statement: "The facts of this case are, we must hope, extraordinary." Id. at 113.

221 Id. at 114-15.

222 Id. at 117 (quoting CAL. Evid. CODE § 621(a) (West 1989)).

$223 I d$. at 115 ("The presumption may be rebutted by blood tests, but only if a motion for such tests is made, within two years from the date of the child's birth, either by the husband or, if the natural father has filed an affidavit acknowledging paternity, by the wife.").

224 Id. at 121.

225 Id. at 129

226 Donald C. Hubin, Daddy Dilemmas: Untangling the Puzzles of Paternity, 13 Cornell J.L. \& Pub. Pol'y 29, 59 (2003) (describing Michael H. as a "genetic father [who] played the role of a social father, represented himself, was represented by the mother as the father of the child, and kept a household with the mother for the benefit of the child").

227 Michael H., 491 U.S. at 131-32.

228 That difficulty has not stopped legal scholars from trying. See, e.g., John Lawrence Hill, What Does It Mean to be a "Parent"? The Claims of Biology as the Basis for Parental Rights, 66 N.Y.U. L. REv. 353, 381 (1991) ("[F] atherhood is a function of the confluence of three factors: the man's biological relationship with the child, his legal or social relationship with the child's 
one can draw at least three conclusions from them about the nature of constitutional parenthood. First, although biological parenthood is relevant, it is not determinative of whether one qualifies as a constitutional parent. Second, determinations of constitutional parenthood are often driven by the need to protect existing families. And third, constitutional parenthood cannot be defined in such a way as to unduly infringe upon the right to reproductive freedom. Here, as further detailed in the next Part, the State Department's interpretation infringes upon the fundamental right of parents by disregarding each of these three underlying principles. ${ }^{229}$

\section{The State Department's Interpretation: Unreasonable AND UNCONSTITUTIONAL}

Having discussed the operation of jus sanguinis within the INA as well as the constitutional protections United States citizens enjoy when it comes to marriage and parenthood, it is the position of this Article that the State Department's attempts to limit jus sanguinis citizenship to only those children of same-sex marriages who have both a legal and a biological connection to the citizen parent ${ }^{230}$ is, first, an unreasonable agency interpretation that is not entitled to Chevron deference and, second, an unconstitutional violation of the citizen parent's fundamental rights to both marriage and parentage.

\section{A. Chevron Deference}

As an initial matter, the State Department's interpretation of INA section 309 is not entitled to Chevron deference. In Christensen v. Harris County, 231 the Supreme Court held that "[i]nterpretations such as those in opinion letters-like interpretations contained in policy statements, agency manuals, and enforcement guidelines, all of which lack the force of law-do not warrant Chevron-style deference." 232 The Court did say that such interpretations are " "entitled to respect' ..., but only to the extent that those interpretations have the

mother, and the extent of his social and psychological commitment to the child." (footnotes omitted)); David D. Meyer, Family Diversity and the Rights of Parenthood, in What Is Parenthood? 124, 130-31 (Linda C. McClain \& Daniel Cere eds., 2013) ("The unwed father cases make clear that biology is relevant, as is past caregiving, diligence, and the nature of the mother's relationships with the biological father and, if she is married, her husband. However, no single criterion controls the constitutional definition of parenthood." (footnote omitted)).

229 See infra Section III.B.2.

230 See supra notes $77-78$ and accompanying text.

231529 U.S. $576(2000)$

232 Id. at 587. 
'power to persuade.' "233 Here, the State Department's interpretation of the relevant INA provisions fails that standard. The plain language of INA section 301 explicitly states that a child acquires U.S. citizenship when born abroad to a married couple consisting of one parent who is a U.S. citizen and the other "an alien" whenever, prior to that child's birth, the citizen parent "was physically present in the United States or its outlying possessions for a period or periods totaling not less than five years, at least two of which were after attaining the age of fourteen years." ${ }^{234}$ Notably, nothing in this provision requires a blood relationship between the child and the legal parent who is a U.S. citizen.

INA section 309, on the other hand, does explicitly require a blood relationship, but by its terms that requirement only applies to children born "out of wedlock." ${ }^{235}$ Additionally, because the INA does not define the phrase "out of wedlock," it must thus be defined using its ordinary meaning. ${ }^{236}$ Under Chevron, it is true that "if the statute is silent or ambiguous with respect to the specific issue, the question for the court is whether the agency's answer is based on a permissible construction of the statute." 237 The Supreme Court has ruled, however, that such deference only applies when "the agency interpretation is not in conflict with the plain language of the statute." 238 As noted above, the plain language of the INA confers citizenship on children of married couples so long as one of the spouses is an American citizen and has resided in the United States for the requisite period. ${ }^{239}$ In light of that statutory scheme, on at least two occasions courts have refused to require any such relationship when adjudicating the citizenship status of children from nontraditional families. ${ }^{240}$ As the Ninth Circuit held in Solis-Espinoza v. Gonzales: "[P]etitioner qualified for citizenship under [INA section 301], despite the lack of a

233 Id. (quoting Skidmore v. Swift \& Co., 323 U.S. 134, 140 (1944)).

234 Immigration and Nationality Act of $1965 \S 301(\mathrm{~g}), 8$ U.S.C. § 1401(g) (2012).

2358 U.S.C. $\S 1409$ (a) (2012).

236 See supra note 49 and accompanying text.

237 Chevron U.S.A. Inc. v. Nat. Res. Def. Council, Inc., 467 U.S. 837, 843 (1984).

238 Nat'l R.R. Passenger Corp. v. Boston \& Maine Corp., 503 U.S. 407, 417 (1992); see K mart Corp. v. Cartier, Inc., 486 U.S. 281, 291-92 (1988) ("If the statute is silent or ambiguous with respect to the specific issue addressed by the regulation, the question becomes whether the agency regulation is a permissible construction of the statute. If the agency regulation is not in conflict with the plain language of the statute, a reviewing court must give deference to the agency's interpretation of the statute." (citations omitted))

239 See 8 U.S.C. $\$ 1401(\mathrm{~g})(2012)$.

240 See supra notes 53-75 and accompanying text (discussing the Solis-Espinoza and Scales cases). 
blood relationship between the child and the U.S. citizen parent, since the statute did not require a blood relationship for citizenship, other than the requirement under [INA section 309] applicable only to a child born out of wedlock." ${ }^{241}$ And, as the Supreme Court has noted, "[w]here Congress includes particular language in one section of a statute but omits it in another section of the same Act, it is generally presumed that Congress acts intentionally and purposely in the disparate inclusion or exclusion." 242

Given then the way in which Congress crafted the statutes at issue, for the State Department to define "out of wedlock" in a way that contravenes the ordinary meaning of the phrase is both unreasonable and impermissible. Thus, the State Department's attempt to redefine "out of wedlock" to exclude the claims of nonbiological children whose parents are nonetheless married to one another is not entitled to Chevron deference.

\section{B. The Fundamental Rights of Same-Sex Parents}

More importantly, it is the position of this Article that beyond Chevron, the interpretation of the INA put forth by the State Department is not only unreasonable, it is unconstitutional. Indeed, even if Congress were formally to amend the INA to incorporate the State Department's current interpretation of the phrase "out of wedlock," the provision would not survive a Fifth Amendment challenge. As discussed earlier, the word "liberty," as that term is used in both the Fifth and Fourteenth Amendments, has been construed to mean much more than freedom from bodily restrain $\mathrm{t}^{243}$ - a point the Court has reiterated even in cases involving immigration.

For instance, as Justice Scalia pointed out in Kerry v. Din, ${ }^{244}$ a 2015 opinion that concerned the due process rights of American citizens to have their alien spouses remain in the United States, the Court has "seen fit on several occasions to expand the meaning of 'liberty' under the Due Process Clause to include certain implied 'fundamental rights." "245 The Court's 1923 opinion in Meyer v. Nebraska ${ }^{246}$ offers what is perhaps the broadest formulation of this interpretation:

\footnotetext{
241 Solis-Espinoza v. Gonzales, 401 F.3d 1090, 1093 (9th Cir. 2005).

242 Gozlon-Peretz v. United States, 498 U.S. 395, 404 (1991) (citation omitted).

243 See supra notes 91-96 and accompanying text.

244135 S. Ct. 2128 (2015).

245 Id. at 2133.

246262 U.S. 390 (1923).
} 
Without doubt, [the word "liberty"] denotes not merely freedom from bodily restraint but also the right of the individual to contract, to engage in any of the common occupations of life, to acquire useful knowledge, to marry, establish a home and bring up children, to worship God according to the dictates of his own conscience, and generally to enjoy those privileges long recognized at common law as essential to the orderly pursuit of happiness by free men. ${ }^{247}$

In Kerry, Scalia acknowledged this precedent, but then added, "this Court is not bound by dicta, especially dicta that have been repudiated by the holdings of our subsequent cases." ${ }^{48}$ Although unclear precisely what portions of Meyer to which Justice Scalia refers, the fact remains that both the right to marry and the right to parent continue to this day as rights protected by the Due Process Clause. ${ }^{249}$ What's more, both rights are infringed by any requirement that a child born to a married couple can only acquire U.S. citizenship if the child is both the legal and biological child of the citizen parent.

\section{The Right to Marry}

With United States v. Windsor ${ }^{250}$ and Obergefell v. Hodges ${ }^{251}$, the Supreme Court has made clear that neither the states nor the federal government can infringe the right of same-sex couples to wed. In Obergefell, Justice Kennedy justified that decision, in part, on the fact that "hundreds of thousands of children are presently being raised" by same-sex couples. ${ }^{252}$ Accordingly, the Court ruled that same-sex marriage should be afforded constitutional protection given that "[m]arriage also affords the permanency and stability important to children's best interests." 253 This language would echo what the Court said two years earlier in Windsor. There, when talking about the impact of DOMA on same-sex families, the Court referenced the children of those families: "[I]t humiliates tens of thousands of children now being raised by same-sex couples. The law in question makes it even more difficult for the children to understand the integrity and closeness of their own family ...."254 Although the full reach of

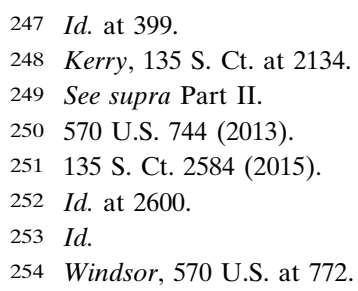


Obergefell and Windsor remains unclear, ${ }^{255}$ the Supreme Court recently held that the right of same-sex couples to wed goes beyond simply allowing them to obtain a marriage license.

Specifically, in Pavan v. Smith, ${ }^{256}$ the Supreme Court reviewed the Arkansas Department of Health's refusal "to issue birth certificates for minor children of married female couples showing the name of the spouse of the mother." ${ }^{257}$ The case concerned the marital presumption that typically provides that, unless he did not consent, the husband of a woman who has been artificially inseminated is the legal father of the resulting child. ${ }^{258}$ The Arkansas statute, for instance, provided that "[i]f the mother was married at the time of either conception or birth or between conception and birth the name of the husband shall be entered on the certificate as the father of the child." 259 Disaggregating the presumption from its gendered language, which indeed some states have done, ${ }^{260}$ would mean that the female spouse of a woman who conceived via artificial insemination would likewise be treated as the child's second legal parent. Arkansas, however, refused to construe the statute in that way, instead only applying the marital presumption to instances where the mother was married to a male.

The Supreme Court of Arkansas upheld the practice, noting, as an initial matter that the "purpose of the statutes is to truthfully record the nexus of the biological mother and the biological father to

255 See, e.g., Mark Strasser, Obergefell, Dignity, and the Family, 19 J. Gender, Race \& Just. 317, 343 (2016) ("It is unclear whether the Court will find that the Fourteenth Amendment protects other rights in the future and also unclear whether Obergefell will provide the basis for expanded equal protection guarantees with respect to orientation-based classifications."); Tom Watts, From Windsor to Obergefell: The Struggle for Marriage Equality Continued, 9 HARv. L. \& Pol'y Rev. S52, S57 (2015) (describing the majority opinion in Windsor as "epically unclear").

256137 S. Ct. 2075 (2017).

257 Smith v. Pavan, 505 S.W.3d 169, 172 (Ark. 2016).

258 See Purvis, supra note 184, at 662 (explaining how the marital presumption helps "provide legal protection for family relationships that already existed: if the husband was willing to continue living with his wife and providing for his family, the familial relationships should be legally protected").

259 Аrk. Code Ann. § 20-18-401(f)(1) (West 2012).

260 See, e.g., McLaughlin v. Jones, 401 P.3d 492, 496 (Ariz. 2017) (holding that the state's marital presumption, which "by its terms only applies to males," must likewise protect the parental rights of a lesbian spouse); Gartner v. Iowa Dep't of Pub. Health, 830 N.W.2d 335, 351 (Iowa 2013) (refusing to strictly construe the gendered language of the state's marital presumption on the basis that "[t]he Gartners are in a legally recognized marriage, just like opposite-sex couples. The official recognition of their child as part of their family provides a basis for identifying and verifying the birth of their child, just as it does for opposite-sex couples."). 
the child." ${ }^{261}$ Accordingly, the court ruled that it must "construe it just as it reads, giving the words their ordinary and usually accepted meaning in common language." 262

The court then turned to Webster's dictionary, noting "that 'husband' is defined as 'a married man.' "'263 In ruling as it did, the court rejected the same-sex couples' equal protection challenge, merely noting that "the female spouse [of a biological mother] does not have the same biological nexus to the child that the biological mother or the biological father has." ${ }^{264}$ Per the Supreme Court of Arkansas, "It does not violate equal protection to acknowledge basic biological truths." 265

On appeal to the Supreme Court, the Court took the unusual step of issuing a summary reversal. The Court began its per curiam opinion by noting that "[a]s this Court explained in Obergefell v. Hodges, the Constitution entitles same-sex couples to civil marriage 'on the same terms and conditions as opposite-sex couples." "266 The Court went on to find that Arkansas's "differential treatment infringes Obergefell's commitment to provide same-sex couples 'the constellation of benefits that the States have linked to marriage.' "267 In other words, the Court held that by making the marital presumption available to married opposite-sex couples, Arkansas could not constitutionally withhold that same benefit from married same-sex couples: "The State uses [the marital presumption] to give married parents a form of legal recognition that is not available to unmarried parents. Having made that choice, Arkansas may not, consistent with Obergefell, deny married same-sex couples that recognition." 268 Thus, Obergefell guarantees more than the bare right to marry. Instead, it also protects married same-sex couples from disparate treatment concerning the incidences of marriage. ${ }^{269}$ Indeed, the holding in Pavan is consistent with Justice Kennedy's observation in Obergefell that "just as a couple vows to

261 Pavan, 505 S.W.3d at 180

262 Id. at 177.

263 Id. at 177-78 (quoting Husband, Webster's Third New InTERnAtional Dictionary 1104 (2002)).

$264 I d$. at 181. In support, the court quoted from the Supreme Court's decision in Nguyen $v$. INS: "To fail to acknowledge even our most basic biological differences . . . risks making the guarantee of equal protection superficial, and so disserving it." Pavan, 505 S.W.3d at 181 (quoting Nguyen v. INS, 533 U.S. 53, 73 (2001)).

265 Pavan, 505 S.W.3d at 181.

266 Pavan v. Smith, 137 S. Ct. 2075, 2076 (2017) (quoting Obergefell v. Hodges, 135 S. Ct. 2584, 2605 (2015)) (citations omitted).

267 Id. at 2077 (citation omitted).

268 Id. at 2078-79.

269 Id. at 2078 ("Obergefell proscribes such disparate treatment."). 
support each other, so does society pledge to support the couple, offering symbolic recognition and material benefits to protect and nourish the union." 270

With that understanding, it becomes apparent that the approach taken by the State Department in requiring a biological relationship between a marital child and the citizen parent ${ }^{271}$ is likewise unconstitutional given the way in which it discriminates against American citizens in same-sex marriages. After all, given that two people of the same sex cannot currently conceive a child using only their genetic material, any child born to a same-sex married couple can only, at best, have a biological connection with one legal parent. ${ }^{272}$ In contrast, opposite-sex marriages can and do produce children who are biologically related to both parents and, thus, would more easily qualify for citizenship at birth.

It is true, of course, that the State Department's definition of "out of wedlock" could conceivably impact both same-sex and opposite-sex couples. Consider, for instance, an American woman who lives in France with her French husband. If the couple were to hire a traditional surrogate to carry their child, the resulting child would be born into the marriage, but would lack a biological connection with the citizen mother. Theoretically, even though the child of a traditional opposite-sex marriage, the State Department's approach would likewise deny that child the right to inherit the legal mother's citizenship. A review of the Foreign Affairs Manual, however, reveals that those cases are unlikely to receive any such scrutiny. Specifically, the Foreign Affairs Manual provides that "whether a claimant meets this statute to establish a derivative claim to U.S. citizenship can usually be

270 Obergefell, 135 S. Ct. at 2601 (emphasis added).

271 See supra notes 77-78 and accompanying text.

272 See John A. Robertson, Gay and Lesbian Access to Assisted Reproductive Technology, 55 CAse W. Res. L. Rev. 323, 324-25 (2004) ("Homosexuals may also seek [assisted reproductive techniques] for infertility, but more often they use them because they cannot reproduce with their partners or others of the same sex."). As advances in assisted reproduction continue, however, even this may change. Indeed, as Professor Michael Boucai has noted,

in vitro gametogenesis (IVG) [is] a process successfully tested in mice, whereby a sperm cell is created from an egg cell-or, alternatively, an egg cell is created from a sperm cell. IVG could allow same-sex couples to have offspring biologically related to both partners and, by eliminating the need for third-party gametes, enable them "to reproduce in a manner similar to fertile straight couples."

Michael Boucai, Is Assisted Procreation an LGBT Right?, 2016 Wis. L. Rev. 1065, 1093 (citation omitted). 
accomplished by review of documentary evidence provided by the claimant." 273

More to the point, the State Department provides that although "[g]enetic testing is most commonly used to verify a parent/child relationship in conjunction with a citizenship case ..., due to the expense, complexity, and logistical delays inherent in parentage testing, genetic testing should be used only if other credible proof does not establish to the satisfaction of the adjudicating officer that the relationship exists." ${ }^{274}$ Finally, the Foreign Affairs Manual does identify three situations that should call into doubt a child's "filiations, despite the existence of a marriage" 275 :

(1) Conception or birth of a child when either of the alleged biological parents was married to another;

(2) Naming on the birth certificate, as father and/or mother, person(s) other than the alleged biological parents; and

(3) Evidence or indications that the child was conceived at a time when the alleged father had no physical access to the mother. ${ }^{276}$

In any of those instances, each of which raises doubt "that the citizen putative "parent' is related by blood to the child," then "the consular officer is expected to investigate carefully." 277

Given then that the State Department does not require genetic testing and only limited circumstances would even prompt an investigation into a biological relationship, most opposite-sex married couples, who presumably could have had a child together, are unlikely to face problems when attempting to establish the citizenship of their children. ${ }^{278}$ In contrast, given the impossibility of a same-sex marriage producing a child that is the legal and biological child of both spouses, same-sex married couples will always trigger an investigation. The Fifth Amendment simply does not tolerate discrimination of this sort. As the Court stated in Windsor, "The liberty protected by the Fifth

273 U.S. Dep't of State, supra note 14, § 1110 app. A, c. (2017); see Kerry Abrams \& R. Kent Piacenti, Immigration's Family Values, 100 VA. L. Rev. 629, 695 n.300, 709 (2014) ("Presumably, as in the immigration context, this evidence would include primary evidence, such as birth certificates and marriage records, and perhaps secondary evidence, such as church and school records.").

274 U.S. Dep't of State, supra note 14, § 1110 app. A, d. (2017).

275 Abrams \& Piacenti, supra note 273, at 695.

276 U.S. Dep't of State, supra note 14, § 1130 app. E, d.

277 Id.

278 See Abrams \& Piacenti, supra note 273, at 695-96 ("It is easy to imagine, however, situations in which a married woman gives birth to a child whose natural father is not the woman's husband without triggering any of these red flags."). 
Amendment's Due Process Clause contains within it the prohibition against denying to any person the equal protection of the laws ... [and] withdraws from Government the power to degrade or demean in the way this law does." 279

\section{Right to Parent}

When it comes to children born abroad who lack a genetic relationship with their citizen parent, even if the State Department treated them all equally regardless of whether they were born into a same-sex or opposite-sex marriage, that interpretation is still unconstitutional as it infringes on the fundamental right to parent a child. As an initial matter, it is important to note that those directly affected by the State Department's approach are, of course, the children. ${ }^{280}$ Typically a party "must assert his own legal rights" and "cannot rest his claim to relief on the legal rights ... of third parties." 281 The Supreme Court has recognized an exception, however, where "the party asserting the right has a close relationship with the person who possesses the right [and] there is a hindrance to the possessor's ability to protect his own interests." ${ }_{282}$ Thus, one must consider here the degree to which the interpretation by the State Department affects the rights of the children's parents-specifically, the parent who is an American citizen and thus deserving of full constitutional protection.

As discussed earlier, legal parentage brings with it a host of rights-rights the federal government, under the Due Process Clause of the Fifth Amendment, cannot infringe. ${ }^{283}$ Indeed, on the basis of Meyer and Pierce, discussed earlier, the Supreme Court has held that "the interest of parents in the care, custody, and control of their children ... is perhaps the oldest of the fundamental liberty interests recognized by this Court." 284 Relatedly, the Court has noted that "[i]t is cardinal with us that the custody, care and nurture of the child reside first in the parents, whose primary function and freedom include preparation for obligations the state can neither supply nor hinder." 285 A number of lower courts have gone one step further, holding that the "constitutional interest in familial companionship and society logically

\footnotetext{
279 United States v. Windsor, 570 U.S. 744, 774 (2013) (citations omitted).

280 See supra notes 77-78 and accompanying text.

281 Warth v. Seldin, 422 U.S. 490, 499 (1975).

282 Sessions v. Morales-Santana, 137 S. Ct. 1678, 1689 (2017) (alteration in original) (quoting Kowalski v. Tesmer, 543 U.S. 125, 130 (2004)).

283 See supra Section II.B.

284 Troxel v. Granville, 530 U.S. 57, 65 (2000).

285 Prince v. Massachusetts, 321 U.S. 158, 166 (1944).
} 
extends to protect children from unwarranted state interference with their relationships with their parents." ${ }^{286} \mathrm{Or}$, as one court put it,

The constitutional interest in the development of parental and filial bonds free from government interference has many avatars. It emerges in a parent's right to control the manner in which his child is reared and educated and in the child's corresponding right not to have the content of his instruction prescribed by the state. It contributes heavily to a parent's right to direct the religious upbringing of his child. And, above all, it is manifested in the reciprocal rights of parent and child to one another's "companionship."287

To discriminate against legal parents solely on the basis of a biological connection infringes that interest and cannot be sustained. Such discrimination, however, is precisely what the State Department's approach does. ${ }^{288}$ It denies citizens, who are the legal but not biological parents to children born abroad, the ability to confer American citizenship on their children - an ability that is not only statutorily mandated $^{289}$ but one that is regularly enjoyed by those citizens who are the biological parents of children born outside the United States. This is not to say that there is a fundamental right to confer citizenship on one's children, ${ }^{290}$ but merely that when it comes to nonbiological but legal parents, the State Department's discrimination impairs their fundamental right to parent their children. ${ }^{291}$ In other words, the constitutional violation rests on the State Department's refusal to recognize the parental status of both legal parents in a same-sex marriage.

The question arises, of course, as to who qualifies as a "parent" for purposes of constitutional protection. Although the Supreme Court has never directly provided an answer, the father's rights cases, discussed earlier, ${ }^{292}$ make clear that there are nonetheless certain prin-

286 Smith v. City of Fontana, 818 F.2d 1411, 1418 (9th Cir. 1987) (emphasis added).

287 Franz v. United States, 707 F.2d 582, 595 (D.C. Cir. 1983) (footnotes omitted).

288 See supra notes 77-78 and accompanying text.

289 See supra notes 43-44 and accompanying text.

290 See Gabriel J. Chin, Is There A Plenary Power Doctrine? A Tentative Apology and Prediction for Our Strange but Unexceptional Constitutional Immigration Law, 14 GeO. IMMIGR. L.J. 257, 277 (2000) ("[T]he Court has made clear that a person born abroad to a citizen parent or parents has the right to citizenship only to the extent Congress so authorizes; the Constitution itself does not grant citizenship to persons born abroad, even to children of citizen-parents.").

291 See Boucai, supra note 272, at 1080 (analyzing the argument that "[lesbian, gay, bisexual, and transgender ("LGBT")] people's unequal access to biological parenthood (or to a particular route to biological parenthood) discriminates against them in their exercise of a fundamental right").

292 See supra Section II.B.2. 
ciples that must guide the determination of constitutional parenthood. Indeed, as discussed earlier, the Court in Obergefell ruled that the "principles and traditions" underlying fundamental right to marry "apply with equal force to same-sex couples." ${ }^{293}$ Similarly, an examination of how the Court has defined "parent" reveals three facets of constitutional parenthood that likewise require that the fundamental right extend beyond biological parentage to encompass all legal parents.

\section{a. Constitutional Parenthood Is Broader Than Biological Parenthood}

If anything can be gleaned about constitutional parenthood from the father's rights cases, it is that "biology is an important but not sufficient condition." 294 Indeed, when it comes to parentage, the Supreme Court has stated that "the mere existence of a biological link does not merit equivalent constitutional protection." 295 Similarly, as Justice Stevens made clear in Caban, "Parental rights do not spring full-blown from the biological connection between parent and child. They require relationships more enduring." 296 Thus, the Court's approach to constitutional parenthood is consistent with what is happening with parental determination at the state level, which has "increasingly deemed married individuals to be legal parents based not on presumed biological connections to their children, but rather on the deliberate parent-child relationships formed inside the marital family."297

Even so, the Court's decisions in the father's rights cases shed even more light on the limited role that biology plays in the resolution of parental identity claims. Although Stanley "created confusion [as to] whether the protections afforded Stanley were to be made available to all unwed fathers or only to those, like him, who had played a part in the socialization of their children," 298 the Court would soon reveal that it was the latter. In fact, in the very next father's rights

293 Obergefell v. Hodges, 135 S. Ct. 2584, 2599 (2015).

294 Elizabeth S. Scott \& Robert E. Scott, Parents as Fiduciaries, 81 VA. L. Rev. 2401, 2457 (1995).

295 Lehr v. Robertson, 463 U.S. 248, 261 (1983).

296 Caban v. Mohammed, 441 U.S. 380, 397 (1979) (Stevens, J., dissenting). Subsequently in Lehr, the Court would adopt this language from Justice Stevens's dissent as the controlling standard. See 463 U.S. at 260.

297 Douglas NeJaime, Marriage Equality and the New Parenthood, 129 Harv. L. Rev. 1185, 1188 (2016).

298 Dolgin, supra note 182, at 651 n.56. 
case, Quilloin v. Walcott, the Court would uphold a statute that required the consent of a nonmarital mother but not a nonmarital father, ${ }^{299}$ finding that it "did not deprive appellant of his asserted rights under the Due Process and Equal Protection Clauses." ${ }^{300}$ Thus, the Court did not hold that Quilloin's constitutional rights were outweighed by the state's interest, but instead that he had no constitutional rights in the first place. ${ }^{301}$ Indeed, one commentator has characterized Quilloin as reflecting "not a curtailment of parental rights, but rather a minimization of the role of biology in assigning those rights." ${ }^{302}$ Not only has the Court discounted the role of biology, but in Michael H., it went so far as to hold that the state of California could constitutionally recognize as the legal father a man who had no biological connection with the child simply by virtue of the fact that he was married to the mother. ${ }^{303}$ In other words, Michael $H$. stands for the proposition that "the law can and will overcome biology." 304

Thus, the State Department's approach to effectively limiting jus sanguinis to biological parenthood is not only at odds with the plain language of the INA, but it defines parenthood in a way that is inconsistent with constitutional parenthood.

\section{b. Constitutional Parenthood Protects Existing Families}

The INA was intended, in part, "to prevent the unwarranted separation of parents from their children." 305 In interpreting constitutional parenthood in the father's rights cases, ${ }^{306}$ the Court has expressed a similar concern with giving effect to intact families. ${ }^{307}$ As

299 See supra notes 198-202 and accompanying text.

300 Quilloin v. Walcott, 434 U.S. 246, 256 (1978).

301 See Emily Buss, "Parental" Rights, 88 VA. L. Rev. 635, 659 (2002) ("Indeed, it never suggested that Mr. Quilloin had any constitutionally protected right whatsoever.").

302 Id.; see Dolgin, supra note 182, at 654 ("The Court in Quilloin, retreating from the more expansive implications of Stanley, explicitly refused constitutional protection to unwed fathers on the basis of biological paternity alone ....").

303 See supra notes 218-25 and accompanying text.

304 Alison S. Pally, Father by Newspaper Ad: The Impact of In Re the Adoption of a Minor Child on the Definition of Fatherhood, 13 Colum. J. Gender \& L. 169, 184 (2004).

305 Morel v. INS, 90 F.3d 833, 841 (3d Cir. 1996); see Solis-Espinoza v. Gonzales, 401 F.3d 1090, 1094 (9th Cir. 2005) ("The [INA] was intended to keep families together. It should be construed in favor of family units and the acceptance of responsibility by family members."); Kaliski v. Dist. Dir. of INS, 620 F.2d 214, 217 (9th Cir. 1980) (noting that the "humane purpose" of the INA is to "reunite families" and that "the purpose of the Act . . . is to prevent continued separation of families").

306 See supra Section II.B.2.

307 See, e.g., In re Raquel Marie X, 559 N.E.2d 418, 424-25 (N.Y. 1990) ("Notably, in Lehr and Quilloin, the Supreme Court also emphasized that the result of permitting stepfather adop- 
one commentator has described it, "A consensus now exists that the Constitution protects the integrity of the family unit." 308 The case of Michael $H$. provides perhaps the clearest example of this approach when the plurality held that "our traditions have protected the marital family" from "inquiries into the child's paternity that would be destructive of family integrity and privacy." ${ }^{309}$ In other words, in Michael $H$. ., "The state's legitimate interest in promoting family integrity . . . was ... controlling." ${ }^{310}$ Quilloin offers another example of the Court's reverence for the intact family. There, the Court dismissed the biological father's attempts to veto a stepparent adoption because, in part, "the result of the adoption in this case is to give full recognition to a family unit already in existence." ${ }^{111}$

Additionally, beyond marriage, the Court has indicated a greater willingness to recognize an individual's parental status when he or she was previously in a marriage-like relationship with the other parent. For instance, in Caban, the Court ruled that the Equal Protection Clause would not tolerate a statute that allowed nonmarital mothers, but not nonmarital fathers, to withhold consent to the adoption of their children. ${ }^{312}$ Of course, the nonmarital father in Caban prevailed largely because he had, unlike the nonmarital fathers in Quilloin and Lehr, played an active role in his children's lives. ${ }^{313}$ Professor Janet Dolgin points out, however, that the decision in Caban also seems to have been heavily influenced by the fact that the nonmarital father had lived "as a natural family" 314 with both the mother and the children: "Caban differed from the traditional position that to achieve legal recognition, a family must include two adults married to each other. But the decision did not eliminate altogether the presence of

tions would be legal recognition of a de facto family already in existence, a State interest it viewed as outweighing the parental interests of the fathers who had not grasped the opportunity to solidify their relationships with their children.”); Cornelia T.L. Pillard \& T. Alexander Aleinikoff, Skeptical Scrutiny of Plenary Power: Judicial and Executive Branch Decision Making in Miller v Albright, 1998 Sup. Cт. Rev. 1, 29 (1998) ("Lehr may more generally be viewed as an expression of the Court's solicitousness toward placement of children with intact nuclear families ....").

308 Traci Dallas, Note, Rebutting the Marital Presumption: A Developed Relationship Test, 88 Colum. L. Rev. 369, 372 (1988).

309 Michael H. v. Gerald D., 491 U.S. 110, 120, 124 (1989). Per the Court, this is true if that inquiry happens to come from the child's biological father. Id. at 121-24.

310 Mary Kay Kisthardt, Of Fatherhood, Families and Fantasy: The Legacy of Michael H. v. Gerald D., 65 Tul. L. Rev. 585, 648 (1991) (emphasis added).

311 Quilloin v. Walcott, 434 U.S. 246, 255 (1978) (emphasis added).

312 See supra text accompanying notes 204-07.

313 See supra text accompanying notes 198-202, 209-16.

314 Caban v. Mohammed, 441 U.S. 380, 389 (1978). 
'family' as a basic precondition for the protection of a biological father's legal paternity." 315 Accordingly, Caban seemingly stands for the proposition that "family rights are relational rights, not individual rights, and family rights arise from and focus on actual parent-child contact." 316

Given, then, the goal of protecting established family units, constitutional protections must attach to all legal parents, whether in a same-sex or opposite-sex relationship and regardless of biological parentage. Given that "every child begins with two (and only two) suppliers of genetic material," to always require a biological connection would increasingly disperse a child's parentage over people from different family units. ${ }^{317}$ After all, in cases of assisted reproduction, those who donated the required genetic material likely have no relationship to one another outside of their participation in the child's conception. Indeed, when it comes to sperm and egg donors, they are typically "strangers who ... become potential parties to the relationship and whose own interests and rights may diverge from those of the [commissioning] couple." 318 As one scholar has noted, the "societal interest [in ensuring a stable family unit for children] is necessarily impaired if the child's legal parentage is split-possibly following protracted litigation-between two individuals who never intended to form a family." ${ }^{19}$ Accordingly, in order to protect intact families, the Court has repeatedly declined to extend constitutional parenthood to individuals based solely on a biological connection to the child in question. ${ }^{320}$

\section{c. Constitutional Parenthood Cannot Infringe upon Reproductive Freedom}

The fundamental right of parents is just one of several rights bundled together in the Court's broader recognition of family privacy, a

315 Dolgin, supra note 182 , at 658.

316 J. Bohl, "Those Privileges Long Recognized”: Termination of Parental Rights Law, the Family Integrity Right and the Private Culture of the Family, 1 CARdozo Women's L.J. 323, 337 (1994).

317 Lynda Wray Black, The Birth of a Parent: Defining Parentage for Lenders of Genetic Material, 92 Neb. L. Rev. 799, 812 (2014); see Susan Frelich Appleton, Presuming Women: Revisiting the Presumption of Legitimacy in the Same-Sex Couples Era, 86 B.U. L. Rev. 227, 270 (2006) ("Every child (at least for now) has two genetic parents, one male and one female.").

318 Radhika Rao, What's So Strange About Human Cloning?, 53 Hastings L.J. 1007, 1012 (2002).

319 Anne Reichman Schiff, Solomonic Decisions in Egg Donation: Unscrambling the Conundrum of Legal Maternity, 80 IowA L. REv. 265, 285 (1995).

320 See supra Section II.B.2. 
category that likewise includes abortion and contraception. ${ }^{321}$ As one scholar has noted, "Rights to abortion, contraception, marriage, kinship, and the custody and rearing of children have, for the most part, sprung up independently of one another, only later converging into a loosely recognized constellation of "family privacy' rights." 322 Indeed, at the heart of all those rights lies the fundamental right to reproductive freedom, which "encompasses the right to reproduce, or in the negative, not to reproduce." ${ }^{323}$ As the famous activist Faye Wattleton has pointed out, "Reproductive freedom is critical to a whole range of issues. If we can't take charge of this most personal aspect of our lives, we can't take care of anything. It should not be seen as a privilege or as a benefit, but a fundamental human right." ${ }^{324}$ It is not surprising, then, that the father's rights cases evidence a strong commitment to defining constitutional parenthood in such a way that it safeguards the right to reproductive freedom.

Consider, for instance, Stanley v. Illinois, where the Court struck down state attempts to classify nonmarital fathers as automatically unfit. ${ }^{325}$ In its ruling, the Court noted its reverence for both the family itself and, more specifically, an individual's right to start a family: "The Court has frequently emphasized the importance of the family. The rights to conceive and to raise one's children have been deemed 'essential,' 'basic civil rights of man,' and '[r]ights far more precious ... than property rights.' "326 Similarly, in striking down the law in question in Caban v. Mohammed, the Court did so on the basis that the statute "excludes some loving fathers from full participation in the decision whether their children will be adopted and, at the same time, enables some alienated mothers arbitrarily to cut off the paternal

321 See Nancy B. Shernow, Recognizing Constitutional Rights of Custodial Parents: The Primacy of the Post-Divorce Family in Child Custody Modification Proceedings, 35 UCLA L. REv. 677, 701-02 (1988) ("The Supreme Court has recognized a fundamental right of family privacy that protects 'marriage, procreation, contraception, abortion, family relationships, and the rearing and education of children' from state interference." (citation omitted)).

322 Meyer, The Paradox of Family Privacy, supra note 159, at 528.

323 Adam Frankel, Note, Cloning Human Beings and the Consumer of the Future: A Worthwhile Endeavor or A Nightmare Come True?, 13 Loy. Consumer L. Rev. 149, 164 (2001); see Brooke D. Rodgers-Miller, Note, Adam and Steve and Eve: Why Sexuality Segregation in Assisted Reproduction in Virginia Is No Longer Acceptable, 11 WM. \& MARy J. Women \& L. 293, 308 (2005) ("[I]n Griswold v. Connecticut, the Court broadened the interpretation it set forth in Skinner, deeming reproductive freedom a fundamental human right.").

324 Marcia Ann Gillespie, Repro Woman: Faye Wattleton Maps Strategy with Marcia Ann Gillespie, Ms., Oct. 1989, at 50.

325 See supra notes 191-96 and accompanying text.

326 Stanley v. Illinois, 405 U.S. 645, 651 (1972) (alterations in original) (citations omitted). 
rights of fathers." ${ }^{27}$ Language such as that used in Stanley and Caban echoes the Court's original description in Meyer v. Nebraska of the fundamental right of parents. ${ }^{328}$ There, when discussing the definition of "liberty," as that term is used in the Due Process Clause, the Court noted that, "[w]ithout doubt, it denotes not merely freedom from bodily restraint but also the right of the individual to," among other things, "establish a home and bring up children." 329

Thus, if the Due Process Clause is to protect fully the right of contemporary American citizens to not only have children, but also to qualify as those children's legal parents with all accompanying rights and responsibilities, the constitutional right cannot be limited to biological parentage. After all, for a variety of reasons, many families simply would not exist but for the reproductive assistance of third parties. ${ }^{330}$ The most obvious example would be an infertile couple whounless they wish to engage in the "time-consuming, costly, and invasive process" 331 of adoption-must resort to assisted reproduction in order to have children. If constitutional parenthood were to require biological parenthood, those couples would never be afforded constitutional protections as parents-protections those couples who can biologically reproduce on their own enjoy as a matter of course. As Douglas NeJaime has persuasively argued, "equality requires treating those traditionally excluded from the parentage regime as full participants." ${ }_{332}$

Here, the State Department's approach defines "parent" so narrowly that when it comes to the conferral of citizenship on their legal children, parents in same-sex marriages face greater obstacles than do

327 Caban v. Mohammed, 441 U.S. 385, 394 (1979); see supra notes 204-07 and accompanying text.

328 See Meyer v, Nebraska, 262 U.S. 390, 400 (1923); Meyer, The Paradox of Family Privacy, supra note 159, at 533 (describing Meyer and Pierce as "now regarded as the foundational family privacy cases").

329 Meyer, 262 U.S. at 399.

330 See, e.g., Douglas NeJaime, The Nature of Parenthood, 126 YALE L.J. 2260, 2285 (2017) ("For centuries, individuals who aspired to parenthood as a meaningful life project had their desires frustrated. Women who could not become pregnant or carry a pregnancy to term, as well as men who suffered from infertility, would live without the families they imagined. Adoption became widespread over the course of the twentieth century and offered a path to parenthood for some, but many either had their attempts rejected by restrictive adoption regimes or simply decided to forego parenting without the possibility of biological children. In the late twentieth century, assisted reproductive technologies . . offered new hope to these individuals . ...").

331 Id. at 2264; see Seema Mohapatra, Assisted Reproduction Inequality and Marriage Equality, 92 Chi.-Kent L. Rev. 87, 88 (2017) ("Because same-sex couples are not able to have biological children with each other without ART, they are functionally infertile.").

332 NeJaime, supra note 330, at 2332. 
parents in opposite-sex marriages. Such discrimination is simply incompatible with the concept of constitutional parenthood, which guarantees parents' rights to the care, custody, and control of their child. Relatedly, by denying same-sex married couples one of the "constellation of benefits" 333 that flows from marriage, the State Department's practice likewise represents an unconstitutional violation of the fundamental right to marriage as that right was enunciated in both Obergefell and Pavan. Accordingly, when it comes to citizen parents in same-sex marriages, the State Department's approach of only recognizing legal parenthood when that person is also a biological parent violates the fundamental right to marriage as well as the fundamental right to parent as safeguarded by the Due Process Clause of the Fifth Amendment.

\section{Conclusion}

The State Department's attempts at excluding the legal children of same-sex couples from immigration benefits simply because those children lack biological ties to the citizen parent are not only unworthy of Chevron deference, they are unconstitutional. After all, the Supreme Court has recognized the right of same-sex couples to marry and has subsequently made clear that whatever rights the state or federal government extends to opposite-sex marriages, it must likewise extend to same-sex couples. One of those rights provided by the federal government is the right to transmit citizenship to one's children. And this right is not a new one. Indeed, as Justice Breyer has pointed out, "Since the founding of our Nation, American statutory law, reflecting a long-established legal tradition, has provided for the transmission of American citizenship from parent to child-even when the child is born abroad." ${ }^{334}$ Thus, to say that this right must be provided equally to those in same-sex marriages should be a fairly unremarkable proposition.

It is true, of course, that Obergefell "opened up new questions about what such access means for a body of family law that regulates same-sex and different-sex couples, biological and nonbiological parents, and marital and nonmarital families." ${ }^{335}$ And those questions are made even more complex by the federalism concerns that reside at the intersection of family law and immigration law. ${ }^{336}$ Indeed, as Professor

\footnotetext{
333 Obergefell v. Hodges, 135 S. Ct. 2584, 2590 (2015).

334 Miller v. Albright, 523 U.S. 420, 471 (1998) (Breyer, J., dissenting).

335 NeJaime, supra note 297, at 1265.

336 See S. Adam Ferguson, Note, Not Without My Daughter: Deportation and the Termina-
} 
David Thronson has explained, "There is no area of law in which the federal government's power is more robust than in immigration and there is no area of law more fully reserved to the states than domestic relations." ${ }_{337}$ Thus, although beyond the discrete focus of this Article, the State Department's interpretation is a particularly timely example of the need for greater clarity on the question of just how far Obergefell extends.

Specifically, given the changing landscape of the American family, ${ }^{338}$ how will constitutional parenthood keep pace with those changes so as to offer meaningful protections to modern families? As discussed earlier, once the Supreme Court ruled that states could no longer restrict legal parenthood to those who were married, the state had to find new ways to deal with nonmarital fathers. ${ }^{339}$ In the next twenty years, the Court would issue five opinions on that subject, the last of which was in $1989 .{ }^{340}$ But with the advent of marriage equality, new questions have arisen. Yet, in the thirty years following the last father's rights case, the Court has remained silent on the issue of constitutional parenthood. It has done so even in the face of such societal changes as advances in and greater availability of assisted reproduction, ${ }^{341}$ the emergence of same-sex marriage as a constitutionally protected right, ${ }^{342}$ and the increased incidences of divorce, cohabitation,

tion of Parental Rights, 22 Geo. Immigr. L.J. 85, 85-86, 89 (2007) (“'In shaping decisions about where [children will reside], family law and immigration law constantly and inevitably interact.' Because immigration law and family law often have divergent goals and policies, the resulting impact on the family can be destructive and traumatic." (alteration in original) (footnote omitted) (quoting Thronson, supra note 97, at 1165)).

337 David B. Thronson, Of Borders and Best Interests: Examining the Experiences of Undocumented Immigrants in U.S. Family Courts, 11 Tex. Hisp. J.L. \& PoL'y 45, 47 (2005) (footnote omitted).

338 See Mary Ann Glendon, Foreword to Reconceiving the Family, at xiii (Robin Fretwell Wilson ed., 2006) ("The late twentieth century was a time of unprecedented changes in family behavior, family law, and ideas about marriage and family life."); Abrams \& Piacenti, supra note 273, at 690 ("As marriage lost its grip on family law in the twentieth century, and as blood and DNA testing began to make genetic parenthood easier to demonstrate, the importance of marital, genetic, functional, and intentional parenthood shifted in family law, providing broadened recognition of new types of parentage."); Michael S. DePrince, Note, Same-Sex Marriage and Disestablishing Parentage: Reconceptualizing Legal Parenthood Through Surrogacy, 100 MinN. L. Rev. 797, 806 (2015) (“[A] new understanding of legal parentage has evolved alongside this starkly changing family landscape.").

339 See supra note 186 and accompanying text.

340 See Michael H. v. Gerald D., 491 U.S. 110 (1989); Lehr v. Robertson, 463 U.S. 248 (1983); Caban v. Mohammed, 441 U.S. 380 (1979); Quilloin v. Walcott, 434 U.S. 246 (1978); Stanley v. Illinois, 405 U.S. 645 (1972).

341 See, e.g., Hill, supra note 228, at 355 ("We now live in an era where a child may have as many as five different 'parents."').

342 See supra Section II.A. 
and remarriage. ${ }^{343}$ In short, the Supreme Court must provide greater guidance on how the fundamental right to parent is to be squared with the new forms of parentage that have become increasingly common.

The State Department's interpretation here highlights that need. With the legalization of same-sex marriage and the availability of assisted reproduction, same-sex couples now enjoy unprecedented access to marriage and childrearing. It is no surprise, then, that questions would arise on how to handle immigration claims by children born abroad into those families. Although this Article's primary purpose is to argue that the State Department's answer, for the reasons discussed above, is unconstitutional, the larger point to be made is that such questions will continue to arise, forcing governmental actors to make decisions. The stories of Ethan Dvash-Banks ${ }^{344}$ and Lucas Alexander Zaccari-Blixt ${ }^{345}$ illustrate the extreme harms that can result when the government makes the wrong decision. Greater guidance from the Supreme Court on the role that constitutional parenthood must play when it comes to regulating twenty-first century families would go a long way in preventing those harms.

343 See Nancy E. Dowd, Multiple Parents/Multiple Fathers, 9 J.L. \& FAм. Stud. 231, 231 (2007) ("Multiple parents . . . are a social reality but not a legal category.").

344 See supra note 2 and accompanying text.

345 See supra note 80 and accompanying text. 